\title{
The Spermine Phosphate-Bound Cyclooctaoxygen Sodium Epigenetic Shell of Euchromatin DNA is Destroyed by the Epigenetic Poison Glyphosate
}

\author{
Andreas J. Kesel $1{ }^{*}{ }^{,}$Eduard A. Struys ${ }^{2}$ and Barbara Cellini ${ }^{3}$ \\ ${ }^{1}$ Chammünsterstr. 47, D-81827 München, Bavaria/Bayern, Germany \\ 2 Metabolic Unit, Department of Clinical Chemistry, University Hospital Vrije Universiteit, 1081 HV \\ Amsterdam, The Netherlands \\ 3 Dipartimento di Neuroscienze, Biomedicina e Movimento, Sezione di Chimica Biologica, Università \\ degli Studi di Verona, 37134 Verona, Italy
}

* Correspondence: andreas.kesel@gmx.de; Tel.: +49 (0)89-453 64500

\begin{abstract}
Oxygen exists in two gaseous and six solid allotropic modifications. An additional allotropic modification of oxygen, the cyclooctaoxygen, was predicted to exist in 1990. The first synthesis and characterization of cyclooctaoxygen as its sodium crown complex, isolated in the form of three cytosine nucleoside hydrochloride complexes, was reported in 2016. Cyclooctaoxygen sodium was synthesized from atmospheric oxygen, or catalase effect-generated oxygen, under catalysis of cytosine nucleosides and either ninhydrin or eukaryotic low-molecular weight RNA. The cationic cyclooctaoxygen sodium complex was shown to bind RNA and DNA, to associate with single-stranded DNA and spermine phosphate, and to be essentially non-toxic to cultured mammalian cells at $0.1-1.0 \mathrm{mM}$ concentration. We postulated that cyclooctaoxygen is formed in most eukaryotic cells from dihydrogen peroxide in a catalase reaction catalysed by cytidine and RNA. A molecular biological model was deduced for a first epigenetic shell of eukaryotic euchromatin. This model incorporates an epigenetic explanation for the interactions of the essential micronutrient selenium (as selenite) with eukaryotic euchromatin. The sperminium phosphate/cyclooctaoxygen sodium complex is calculated to cover the actively transcribed regions $(2.6 \%)$ of bovine lymphocyte interphase genome. Cyclooctaoxygen seems to be naturally absent in hypoxia-induced highly condensed chromatin, taken as a model for eukaryotic metaphase/anaphase/early telophase mitotic chromatin. We hence propose that the cyclooctaoxygen sodium-bridged spermine phosphate and selenite coverage serves as an epigenetic shell of actively transcribed gene regions in eukaryotic 'open' euchromatin DNA. The total herbicide glyphosate (ROUNDUP) and its metabolite (aminomethyl)phosphonic acid (AMPA) are proved to represent 'epigenetic poisons', since they both selectively destroy the cyclooctaoxygen sodium complex. This definition is of reason, since the destruction of cyclooctaoxygen is sufficient to bring the protection shield of human euchromatin into collateral epigenetic collapse.
\end{abstract}

Keywords: spermine, cyclooctaoxygen, DNA, selenium, glyphosate, AMPA 


\section{Introduction}

In 1677 Antoni van Leeuwenhoek discovered [1] the characteristic crystals of spermine phosphate (spermine $\times 2 \mathrm{H}_{3} \mathrm{PO}_{4} \times 6 \mathrm{H}_{2} \mathrm{O}$ ) [2] in matured native human semen (Figure 1). Since then, there was collected conclusive evidence that human chromosomal DNA is closely associated with spermine phosphate [2]. The interaction of oxygen species with DNA has until recently only being focused on oxidative DNA damage and its pathophysiological consequences [3]. In 2015 Kirmes et al. reported an unprecedented interaction of eukaryotic chromatin DNA structure with atmospheric oxygen partial pressure [4]. Under switching to hypoxic conditions $\left(1 \% \mathrm{O}_{2}, 5 \% \mathrm{CO}_{2}, 94 \% \mathrm{~N}_{2}\right)$ the murine cardiomyocyte HL-1 cell chromatin rendered itself highly condensed, accompanied by redistribution of the polyamine pool (mainly spermine and spermidine) to the nucleus [4]. In 2016 Kesel et al. showed [5] that eukaryotic single-stranded DNA (ssDNA) binds a new allotropic form of oxygen, the cyclooctaoxygen (cyclo-Os) (Figure 2A), in form of its sodium $\left(\mathrm{Na}^{+}\right)$complex (cyclo-O $-\mathrm{Na}^{+}$) (Figure 2B), especially when in coordination to spermine phosphate (sperminium phosphate) [5]. A model for a logically resulting first epigenetic shell of eukaryotic DNA in vivo was proposed (Figure 3) [5]. Also a partial substitution of the sperminium $\left(\mathrm{C}_{10} \mathrm{H}_{30} \mathrm{~N}_{4}{ }^{4+}\right)$-bound monohydrogen phosphate $\left(\mathrm{HPO}_{4}{ }^{2-}\right)$ anions by hydrogen selenite $\left(\mathrm{HSeO}_{3}{ }^{-}\right.$ ) anions was postulated during these investigations [5], thereby providing an explanation for the wellknown, but 'mysterious' [6], augmenting effects of the essential micronutrient selenium on eukaryotic genome integrity and chromosomal DNA stability [6,7].

\section{Results}

\subsection{Cyclooctaoxygen}

The chemical element oxygen exists in eight well-characterized allotropic modifications, dioxygen $\left(\mathrm{O}_{2}\right)$, ozone $\left(\mathrm{O}_{3}\right)$, and the solid -, $\quad-, \quad-, \quad-, \quad$ - and -oxygen phases [8]. The $\quad-, \quad$ - and -phases exist at ambient pressure and low temperature [5,8,9]. At ambient temperature under pressure of 5.4 GPa oxygen solidifies into the -phase, then at 9.6 GPa into the orthorhombic 'orange' -phase, and, successively, at $10 \mathrm{GPa}$ into the monoclinic 'dark red' -phase. Above $96 \mathrm{GPa}$-oxygen is transformed into the metallic -phase which exhibits superconductivity [5,8,9]. The 'red' -phase revealed the structure of two combined tetroxetane (cyclo- $\left.\mathrm{O}_{4}\right)$ rings, giving rise to rhombohedral $\mathrm{O}_{8}$ clusters [9]. In 1990 a ninth allotropic modification of oxygen was theoretically predicted [10], the cyclooctaoxygen (cyclo-Os, octoxocane) (Figure 2A) [8,10], assumed to exist in analogy to the common modification of elemental sulfur, cyclooctasulfur (cyclo-Ss, octathiocane) [10]. Our group reported [5] the (biomimetic) synthesis, isolation, chemical characterization, biochemical and epigenetic significance of cyclo- $\mathrm{O}_{8}$ in form of its sodium crown complex, (octoxocane- $\left.{ }^{4} \mathrm{O}^{1}, \mathrm{O}^{3}, \mathrm{O}^{5}, \mathrm{O}^{7}\right)$ sodium $\left(1+\right.$ ) or cyclo- $\mathrm{O}_{8}-\mathrm{Na}^{+}$ (Figure 2B) [5].

\subsection{The Isolation of Two Cyclooctaoxygen Complexes NC and $d N C$}

In an endeavor to gain new antiviral substances, the reported reaction [11] of the RNA nucleoside cytidine with ninhydrin on reflux was re-examined. Instead of cytidine, cytidine hydrochloride (cytidine $\times \mathrm{HCl}$ ) was utilized. The reported reaction [11] did not proceed, instead a crystalline material NC could be isolated which gave not the elemental analysis of cytidine $\times \mathrm{HCl}$. It could be substantiated that NC contained an inert material not being salt $(\mathrm{NaCl})$, since the Fourier transform infrared (FT-IR) spectrum of $\mathrm{NC}$ differed from that of cytidine $\times \mathrm{HCl}$. According to elemental analysis this inert material could account for one $\mathrm{O}_{2}$ and a quarter of $\mathrm{NaCl}$ pro one cytidine $\times \mathrm{HCl}$. In consequence, the formula was multiplied fourfold and this resulted in an oxygen 8-ring, cyclo-Os (Figure 2A), coordinated to one $\mathrm{Na}^{+}$(Figure 2B). 
The interpretation of the electrospray ionization mass spectrometry (ESI-MS) spectrum of NC actually proved the inclusion of cyclo-Os- $\mathrm{Na}^{+}$in NC. Since in the proton nuclear magnetic resonance $\left({ }^{1} \mathrm{H}-\mathrm{NMR}\right)$ spectrum of $\mathrm{NC}$, in comparison to the ${ }^{1} \mathrm{H}-\mathrm{NMR}$ reference spectrum of cytidine $\times \mathrm{HCl}$, the differentially affected resonances were the $4-\mathrm{NH}_{2}$, the $3-\mathrm{NH}^{+}$, and the $\mathrm{H}-5$ protons of the protonated cytidine, it was assumed [5] that the points of coordination between cyclo- $\mathrm{O}_{8}-\mathrm{Na}^{+}$and cytidine $\times \mathrm{HCl}$ are the two $4-\mathrm{NH}_{2}$ hydrogens and one non- $\mathrm{Na}^{+}$-coordinated (free) oxygen of cyclo-Os- $\mathrm{Na}^{+}$. Consequently, a formula for NC was elaborated: cytidine hydrochloride - aqua(chloro)(octoxocane- $\quad{ }^{4} \mathrm{O}^{1}, \mathrm{O}^{3}, \mathrm{O}^{5}, \mathrm{O}^{7}$ )sodium (4:1) (Figure 4A) [5].

The new ninhydrin reaction was in turn applied on 2'-deoxycytidine hydrochloride (2'deoxycytidine $\times \mathrm{HCl}$ ). A crystalline material $\mathbf{d N C}$ could be isolated which gave not the elemental analysis of 2'-deoxycytidine $\times \mathrm{HCl}$. The FT-IR spectrum of $\mathbf{d N C}$ differed from that of 2'-deoxycytidine $\times \mathrm{HCl}$. The interpretation of the ESI-MS spectrum of $\mathbf{d N C}$ proved the inclusion of cyclo-Os-Na+ in $\mathbf{d N C}$. In analogy to $\mathrm{NC}$, supported by ${ }^{1} \mathrm{H}-\mathrm{NMR}$ spectroscopy of $\mathrm{dNC}$, a formula for $\mathrm{dNC}$ could be constructed: 2'deoxycytidine hydrochloride - aqua(chloro)(octoxocane- $\left.{ }^{4} \mathrm{O}^{1}, \mathrm{O}^{3}, \mathrm{O}^{5}, \mathrm{O}^{7}\right)$ sodium (2:1) (Figure 4B) [5].

\subsection{Catalase Assay of NC and Candida utilis RNA - Biomimetic Synthesis of RC - Structure Proof for Cyclooctaoxygen}

It was questioned if cyclo-Os- $\mathrm{Na}^{+}$could be produced in biomimetic reactions, and it was considered that in the two ninhydrin reactions atmospheric oxygen was the source of the oxygen atoms in cyclo-Os. Our interest concentrated on oxygen formation by possible catalase effects under physiological conditions. The catalase effect is the disproportionation of dihydrogen peroxide $\left(\mathrm{H}_{2} \mathrm{O}_{2}\right)$ into oxygen and water: $2 \mathrm{H}_{2} \mathrm{O}_{2} \rightarrow \mathrm{O}_{2}+2 \mathrm{H}_{2} \mathrm{O}$. As a catalyst RNA was selected, since RNA can exhibit enzymatic (ribozyme) activities in vivo [12,13]. The selected eukaryotic RNA was Candida utilis anamorph yeast low-molecular weight RNA. This RNA consists of transfer RNAs (tRNAs) and the C. utilis 5S ribosomal RNA (rRNA) [5]. As a result it was discovered that NC catalysed oxygen formation from $\mathrm{H}_{2} \mathrm{O}_{2}$ (catalase effect) weakly in presence of $\mathrm{NaHCO}_{3}$, and strongly in presence of both C. utilis RNA and $\mathrm{NaHCO}_{3}$ [5]. Interestingly, NC could be fully substituted by cytidine $\times \mathrm{HCl}$. Multiple controls assured that oxygen neither was produced spontaneously, nor from any other relevant combination of the utilized reagents. Taken together, the nucleoside cytidine, not cyclo-O $8-\mathrm{Na}^{+}$, was responsible for the catalase activity expressed in presence of $\mathrm{H}_{2} \mathrm{O}_{2}$ and C. utilis RNA under biomimetic conditions. It was decided to exactly scale-up (21-fold) the catalase assay protocol starting with cytidine $\times \mathrm{HCl}$ and C. utilis RNA to detect any cyclo-O $-\mathrm{Na}^{+}$formation under biomimetic conditions. From this preparation a cyclo$\mathrm{O}_{8}-\mathrm{Na}^{+}$-containing crystalline material $\mathbf{R C}$ could be isolated which gave not the elemental analysis of cytidine $\times \mathrm{HCl}$. If the $C$. utilis RNA was omitted, no product $\mathrm{RC}$ could be isolated, only cytidine $\times \mathrm{HCl}$. Based on ${ }^{1} \mathrm{H}-\mathrm{NMR}$ spectroscopy and FT-IR spectroscopy of RC, a formula for RC could be constructed: cytidine hydrochloride - -chloro( -hydroxy)bis(octoxocane- ${ }^{4} \mathrm{O}^{1}, \mathrm{O}^{3}, \mathrm{O}^{5}, \mathrm{O}^{7}$ )disodium (1:2) (Figure 4C) [5].

Final structure proof for the existence of cyclo-Os was obtained from the ESI-MS of RC (Figure 5). Cluster cations of heptoxazocan-8-ium - octoxocane - $\mathrm{Na}^{35} \mathrm{Cl}(1: 2: m)(m=0-6)$ were observed, together with characteristic +2 isotope peaks resulting from substitution of one ${ }^{37} \mathrm{Cl}$ for ${ }^{35} \mathrm{Cl}(m=1-6)$, and together with -2 peaks of heptoxazocan-8-iumyl - octoxocane (1:2) cluster radical cations $(m=0-6)$ (Figure 5). Clusters of $\left[(\text { cytidine })_{2}+\mathrm{Na}+(\mathrm{NaCl})_{n}\right]^{+}(n=0-5)$ were also observed (Figure 5). Structure proving was the missing of a +2 peak for $m=0$ (Figure 5, inset), indicating that any $\mathrm{NaCl}$ is absent in this radical cation $\mathrm{m} / \mathrm{z}$ 383.9907. The nitrogen insertion into cyclo-Os to give heptoxazocane $\left(\mathrm{HNO}_{7}\right)$ resulted from mass spectrometric generation of ammonia $\mathrm{NH}_{3}$ from cytidine $\left(\mathrm{O}_{8}+\mathrm{NH}_{3} \rightarrow \mathrm{HNO}_{7}+\mathrm{H}_{2} \mathrm{O}\right)$. 


\subsection{Binding of NC to Candida utilis RNA}

In view of the biomimetic generation of the cyclo-O8- $\mathrm{Na}^{+}$-containing coordination complex $\mathbf{R C}$, the question arose if cyclo-Os- $\mathrm{Na}^{+}$could bind to nucleic acids, because of the mere electrostatic attraction of the cyclo-Os- $\mathrm{Na}^{+}$cation towards the negatively charged phosphate backbone of RNA and DNA. For this purpose thin-layer chromatographic mobility shift assays [14] were applied on specific nucleic acids and the cyclo-O $\mathrm{O}_{8} \mathrm{Na}^{+}$contained in NC. Firstly, the affinity of the cyclo-O $8-\mathrm{Na}^{+}$towards C. utilis lowmolecular weight RNA was investigated [5]. It was found that the cyclo-Os- $\mathrm{Na}^{+}$contained in NC retained the chromatographic shift of C. utilis 5S rRNA, but not the chromatographic shift of C. utilis tRNAs. Interestingly, since work conditions were not human skin ribonuclease (RNase)-free, the RNase A digestion products of $C$. utilis $5 S$ rRNA were separated chromatographically [5]. These dinucleotide 2', $3^{\prime}$ cyclic phosphates (products of RNase A digestion) result from human skin RNase 7-mediated digestion of C. utilis 5S rRNA [5]. The structures of these dinucleotides can be deduced, since RNase 7 belongs to the RNase A superfamily [5]. The cyclo-O $\mathrm{O}_{8}-\mathrm{Na}^{+}$contained in $\mathrm{NC}$ bound strongly to these dinucleotide $2^{\prime}, 3^{\prime}$-cyclic phosphates, since their chromatographic shifts were significantly retarded. Controls were included to differentiate the sole binding of cytidine $\times \mathrm{HCl}$ to the RNA targets by Watson-Crick base pairing [15] from the indicative cyclo- $\mathrm{O}_{8}-\mathrm{Na}^{+}$plus cytidine $\times \mathrm{HCl}$ binding to the RNA targets.

\subsection{Binding of NC to Salmon Testes Single-Stranded DNA and Spermine Phosphate}

Accordingly, the affinity of the cyclo-Os- $\mathrm{Na}^{+}$contained in NC towards salmon testes singlestranded deoxyribonucleic acid [ssDNA, generated by sonication of salmon genomic double-stranded DNA (dsDNA); extracted after sonication by phenol-chloroform method and precipitated with ethanol; the sonication shears the genomic dsDNA to produce ssDNA fragments in the range of 587 to $831 \mathrm{bp}]$ was investigated (Figure 6) [5]. It was found that the cyclo-Os- $\mathrm{Na}^{+}$contained in NC retained the chromatographic shift of cytidine $\times \mathrm{HCl}$ complexed to ssDNA (Figure 6). As control served cytidine $\times \mathrm{HCl}$ complexed to ssDNA. The affinity of the cyclo-Os- $\mathrm{Na}^{+}$contained in $\mathrm{NC}$ towards salmon testes ssDNA in absence and presence of spermine $\times 1 \frac{1 / 3}{3}$ (sodium dihydrogen phosphate) $\times 9 \mathrm{H}_{2} \mathrm{O}$ was investigated [5]. It was found that the spermine $\times 1 \frac{1 / 3}{3}$ (sodium dihydrogen phosphate) $\times 9 \mathrm{H}_{2} \mathrm{O}$ changed the chromatographic shift of the cytidine $\times \mathrm{HCl}$ in NC-complexed ssDNA. As controls served cytidine $\times \mathrm{HCl}$ complexed to ssDNA in absence and presence of cyclo- $\mathrm{O}_{8}-\mathrm{Na}^{+}$, and cytidine $\times \mathrm{HCl}$ complexed to ssDNA in presence of spermine $\times 1 \frac{1 / 3}{3}$ (sodium dihydrogen phosphate) $\times 9 \mathrm{H}_{2} \mathrm{O}$ [5]. Taken together, cyclo-Os- $-\mathrm{Na}^{+}$ contained in NC had the ability to bind to RNA dinucleotide $2^{\prime}, 3^{\prime}$-cyclic phosphates, eukaryotic 5S rRNA, eukaryotic ssDNA, and to construct a ternary complex with spermine phosphate and eukaryotic ssDNA.

\subsection{In Vitro Biological Effects of NC and dNC on Cultured Mammalian Cells}

The in vitro biological effects of $\mathbf{N C}$ and $\mathbf{d N C}$ on the growth of cultured cells, freshly explanted human primary (human peripheral blood mononuclear cells, PBM cells), immortalized T-lymphoblastic (CCRF-CEM) and monkey kidney normal epithelial (Vero), were investigated [5]. NC and dNC were non-toxic to PBM cells, but stimulated the growth of CCRF-CEM cells. This pointed to a catalase effect exerted by $\mathbf{N C}$ and $\mathbf{d N C}$, since CCRF-CEM cells are extremely sensitive to $\mathrm{H}_{2} \mathrm{O}_{2}$ [5], and scavenging of $\mathrm{H}_{2} \mathrm{O}_{2}$ by 'catalase factors' is CCRF-CEM cell growth rate-limiting [5]. Since NC was more active as a growth stimulant for CCRF-CEM cells than $\mathbf{d N C}$, the responsible 'catalase factors' should be the nucleoside hydrochlorides, not the equimolar cyclo-Os- $\mathrm{Na}^{+}-$content in NC and $\mathbf{d N C}$. NC and $\mathbf{d N C}$ exhibited no significant in vitro antiviral activities against the retro-transcribing human immunodeficiency 
type 1 and hepatitis B viruses (HIV-1 strain LAI and HBV subtype ayw) [5]. NC showed no significant in vitro inhibiting activity versus the replication of influenza A (H1N1 and H5N1) and chikungunya (strain S-27) viruses, and no significant in vitro inhibiting activity on Middle East respiratory syndrome (MERS) coronavirus (MERS-CoV strain Erasmus Medical Center/2012) replication [5]. In summary, cyclo-Os- $\mathrm{Na}^{+}$ is, contrary to expectation, essentially non-toxic to human cells, and cytidine in conjunction with RNA acts as a catalyst in producing cyclo- ${ }_{8}-\mathrm{Na}^{+}$from ubiquitous [5] $\mathrm{H}_{2} \mathrm{O}_{2}$ through a catalase reaction in cultured human cells.

\subsection{Color Assay for Cyclo-Os-Na+ Contained in $\mathrm{RC}$ - Destruction of Cyclo-O $\mathrm{O}_{8}-\mathrm{Na}^{+}$by the Glyphosate Metabolite} (Aminomethyl)phosphonic Acid

The cyclo-O8- $\mathrm{Na}^{+}$complex [ -chloro( -hydroxy)bis(octoxocane- ${ }^{4} \mathrm{O}^{1}, \mathrm{O}^{3}, \mathrm{O}^{5}, \mathrm{O}^{7}$ )disodium] contained in $\mathrm{RC}\left(4 \mathrm{~mol}\right.$ cyclo-O ${ }_{8}-\mathrm{Na}^{+}$pro mol cytidine $\left.\times \mathrm{HCl}\right)$ reacted with potassium iodide and potato starch to an intensely colored (reddish violet) $\left[\left(\right.\right.$ cyclo-Os- $\left.\left.\mathrm{Na}^{+}\right) 2\left(\mathrm{I}_{4}{ }^{2-}\right)\right]$-amylose complex $[\mathrm{RC}+\mathrm{KI}+$ starch (5)] (Figure 7) which was destroyed by the glyphosate metabolite (aminomethyl)phosphonic acid (AMPA) $[\mathrm{RC}+\mathrm{KI}+$ starch + AMPA (6)]. The nature of this complex is based on the starch-catalysed formation of tetraiodide $\mathrm{I}^{2-}$ [(I-I-I-I $\left.)^{2-}\right]$, which is known to be of ruby red color in crystalline form [16], was frequently observed in crystals [17], and was theoretically predicted to exist in solution [18]. The tetraiodide $\mathrm{I}_{4}{ }^{2-}$ is in turn complexed to cyclo- $\mathrm{O}_{8}-\mathrm{Na}^{+}$and inserted into the amylose helix (Figure $8 \mathrm{~A}$ and $8 \mathrm{~B})$. Multiple controls excluded that the [(cyclo- $\left.\left.\mathrm{O}_{8}-\mathrm{Na}^{+}\right)_{2}\left(\mathrm{I}_{4}{ }^{2-}\right)\right]$-amylose complex is formed (i) in blanks [KI (1), and KI + starch (2)], (ii) without starch [RC + KI (3)], and (iii) from AMPA and RC + KI [RC + KI + AMPA (4)] (Figure 7). That the reddish violet complex involved triiodide $\mathrm{I}^{-}\left[(\mathrm{I}-\mathrm{I}-\mathrm{I})^{-}\right]$or pentaiodide $\mathrm{I}^{-}$ [(I-I-I-I-I)-] anions could be excluded by the observed color. Triiodide $\mathrm{I}^{-}$is deep brown [19] and pentaiodide $\mathrm{I}_{5}$ is deep blue in color [20]. Pentaiodide $\mathrm{I}_{5}$ is also deep blue in the well-known complex with starch [21]. Furthermore, the [(cyclo-O $\left.\left.-\mathrm{Na}^{+}\right)_{2}\left(\mathrm{I}_{4}{ }^{2-}\right)\right]$-amylose complex was (i) reduced (decolorized) by Lascorbic acid (vitamin C), and (ii) the residual color after AMPA-catalysed destruction of cyclo-Os was pale pink (rosé) in color, not intense blue. This proved that (i) the reddish violet complex contained reducible iodine units, and (ii) did not contain the reducible iodine units as triiodide, pentaiodide and/or other higher polyiodides [22]. Without starch no [(cyclo- $\left.\left.\mathrm{O}_{8}-\mathrm{Na}^{+}\right) 2\left(\mathrm{I}_{4}{ }^{2-}\right)\right]$ and/or iodine was formed, as was proved by deuterated chloroform $\left(\mathrm{CDCl}_{3}\right)$ extraction of the incubated $\mathrm{RC}+\mathrm{KI}(3)$ and $\mathrm{RC}+\mathrm{KI}+\mathrm{AMPA}$ (4) solutions (Figure 7). Therefore, the iodine in tetraiodide $\mathrm{I}_{4^{2-}}$ must have being formed by starch catalysis.

A logically deduced catalytic 'rolling-circle' mechanism for the AMPA-catalysed degradation of cyclo-Os is hence proposed (Figure $8 \mathrm{C}$ ). AMPA exhibits three acid dissociation constants: $\mathrm{p} K_{\mathrm{a} 1}=0.9$ (phosphonic acid, $1^{\text {st }}$ ), $\mathrm{pK}$ a2 $=5.6$ (phosphonic acid, $2^{\text {nd }}$ ), $\mathrm{pK}_{\mathrm{a} 3}=10.2$ (primary ammonium $\mathrm{R}-\mathrm{NH}_{3}{ }^{+}$) [23]. Therefore, AMPA is fully (zwitter)ionized at physiological $\mathrm{pH}$ 7.4. One anionic oxygen of the phosphonate group binds to the sodium cation in cyclo- $\mathrm{O}_{8}-\mathrm{Na}^{+}$, the other anionic phosphonate oxygen splits the cycloocytooxygen ring creating a phosphonate-esterified nonaoxidanide which is stabilized by ionic binding to the primary ammonium cation of AMPA. The phosphonate-esterified nonaoxidanide eliminates four oxygen $\mathrm{O}_{2}$ molecules by a 'rolling-circle' cascade, in reversal of the proposed [5] synthesis of cyclooctaoxygen, yielding AMPA and $\mathrm{Na}^{+}$. This would be clearly a catalytic mechanism, since AMPA is regenerated in the catalytic cycle. Hence AMPA is able to destroy many cyclo- ${ }_{8}-\mathrm{Na}^{+}$complexes without being consumed itself.

To exclude that the destruction of cyclo-O $8-\mathrm{Na}^{+}$by AMPA is an artifact, it was tested if AMPA reduces (decolorizes) iodine in near equimolar mixture (Figure 7). In all variations tested, including a blank control, AMPA was not oxidized by iodine, and, in turn, did not reduce (decolorize) iodine 
molecules. Therefore, the AMPA-catalysed destruction of cyclo-Os was selective, and not a mere reduction of the tetraiodide $\mathrm{I}_{4}{ }^{2-}\left[(\mathrm{I}-\mathrm{I}-\mathrm{I}-\mathrm{I})^{2-}\right]$-contained iodine unit in the $\left[\left(\text { cyclo- } \mathrm{O} 8-\mathrm{Na}^{+}\right)_{2}\left(\mathrm{I}_{4}{ }^{2-}\right)\right]-$ amylose complex.

\subsection{Color Assay for Cyclo-Os- $\mathrm{Na}^{+}$Contained in $\mathrm{RC}$ - Destruction of $\mathrm{Cyclo}-\mathrm{O} s-\mathrm{Na} a^{+}$by Glyphosate and ROUNDUP®}

The developed color assay was applied onto the free acid of glyphosate and the monosodium salt of glyphosate contained in ROUNDUP ${ }^{\circledR}$ GRAN granules. The colored [(cyclo- $\left.\left.\mathrm{O}_{8}-\mathrm{Na}^{+}\right)_{2}\left(\mathrm{I}_{4}{ }^{2-}\right)\right]-$ amylose complex [RC + KI + starch (1)] (Figure 9) was destroyed by glyphosate [RC + KI + starch + glyphosate (2)] and ROUNDUP® GRAN [RC + KI + starch + glyphosate-Na (3)]. Without starch no [(cyclo-O $\left.\left.{ }_{8}-\mathrm{Na}^{+}\right)_{2}\left(\mathrm{I}_{4}{ }^{2}\right)\right]$ and/or other color complex was formed, as was proved by the controls RC + KI + glyphosate (4) and RC + $\mathrm{KI}+$ glyphosate-Na (5) (Figure 9). The RC + KI + starch + glyphosate (2) solution was colored yellow by the strong acid glyphosate (Figure 9), through $\mathrm{H}^{+}$action onto starch producing the characteristic yellow dextrins [24]. Glyphosate exhibits four acid dissociation constants: $\mathrm{p} K_{\mathrm{a} 1}=0.78$ (phosphonic acid, ${ }^{\text {st }}$ ), $\mathrm{p} K_{\mathrm{a} 2}$ $=2.29$ (carboxylic acid), $\mathrm{p} K_{\mathrm{az}}=5.96$ (phosphonic acid, $2^{\mathrm{nd}}$ ), $\mathrm{pK}$ a4 $=10.98$ (primary ammonium $\mathrm{R}-\mathrm{NH}_{3}{ }^{+}$) [23]. Therefore, glyphosate (free acid) represents a strong acid.

A logically deduced catalytic 'rolling-circle' mechanism for the glyphosate-catalysed degradation of cyclo-O $\mathrm{O}_{8}$ is hence proposed (Figure 10). One anionic oxygen of the phosphonate group binds to the sodium cation in cyclo-Os- $\mathrm{Na}^{+}$, the other anionic phosphonate oxygen splits the cycloocytooxygen ring creating a phosphonate-esterified nonaoxidanide which is stabilized by ionic binding to the secondary ammonium cation of glyphosate. The phosphonate-esterified nonaoxidanide eliminates four oxygen $\mathrm{O}_{2}$ molecules by a 'rolling-circle' cascade, yielding glyphosate and $\mathrm{Na}^{+}$in a catalytic mechanism. Glyphosate is regenerated in the catalytic cycle. Glyphosate is able to destroy many cyclo- $\mathrm{O}_{8}-\mathrm{Na}^{+}$complexes without being consumed itself.

To exclude that the destruction of cyclo-Os- $\mathrm{Na}^{+}$by glyphosate is an artifact, it was tested if glyphosate, or glyphosate- $\mathrm{Na}$, reduces (decolorizes) iodine in near equimolar mixture (Figure 9). Glyphosate was not oxidized by iodine, and, in turn, did not reduce (decolorize) iodine molecules. Therefore, the glyphosate-catalysed destruction of cyclo-O 8 was selective. To confirm the general nature of the color assay, it was extended to the cyclo-O $\mathrm{O}_{8}-\mathrm{Na}^{+}$contained in $\mathrm{NC}\left(1 \mathrm{~mol}\right.$ cyclo-O $8-\mathrm{Na}^{+}$pro $4 \mathrm{~mol}$ cytidine $\times \mathrm{HCl})$ [5]. The reddish violet $\left[\left(\text { cyclo- }-\mathrm{O}_{8}-\mathrm{Na}^{+}\right)_{2}\left(\mathrm{I}_{4}{ }^{2-}\right)\right]$-amylose complex was indeed formed from NC (Figure 9), but much more slowly (> $10 \mathrm{~h}$ ) than from RC.

\subsection{Enzymatic Investigations with the Glyphosate Metabolite (Aminomethyl)phosphonic Acid}

AMPA was tested for being accepted as an enzymatic substrate for human mitochondrial aminobutyric acid transaminase (ABAT) [25], and wild-type human liver peroxisomal alanine:glyoxylate aminotransferase (AGT) [26]. Both enzymes were selected because of the chemical analogy between AMPA and -alanine/L-alanine. ABAT represents also a -alanine transaminase [25]. Data obtained with human AGT indicate that the enzyme is barely able to catalyse the half-transamination of AMPA, with a rate of $k_{\mathrm{cat}}=-0.0108 \pm 0.0009 \mu \mathrm{M} \mathrm{PLP} / \mathrm{h} / \mu \mathrm{M}$ AGT consumed, or $k_{\mathrm{cat}}=-0.0104 \pm 0.0009 \mu \mathrm{M}$ $\mathrm{PMP} / \mathrm{h} / \mu \mathrm{M}$ AGT formed (Figure 11A), respectively (PLP, pyridoxal 5'-phosphate; PMP, pyridoxamine 5'phosphate). This value is approximately 16.2 million-fold lower than that of the physiological transamination of L-alanine (human wild-type AGT: $k_{\mathrm{cat}}=45 \pm 2 \mathrm{~s}^{-1} ; k_{\mathrm{cat}}=162,000 \mathrm{~h}^{-1}$ ) [26]. 


\section{Discussion}

One reason why the cyclooctaoxygen sodium-bridged spermine phosphate epigenetic shell of in vivo DNA was overlooked until now should be its destruction during DNA purification by the classical phenol extraction method of Schuster, Schramm \& Zillig [5]. This original phenol extraction, although variously modified for nowadays use [27], consistently precipitates the spermine as sperminediium (terminal $\mathrm{NH}_{3}{ }^{+}$) di(phenolate) at $\mathrm{pH}$ 7.9-8.0 [27], since the $\mathrm{pK}$ a value of phenol is 9.97 [potentiometric titration in $\mathrm{H}_{2} \mathrm{O}, 25{ }^{\circ} \mathrm{C}$, ionic strength $\left.(\mathrm{NaCl}) 0.1\right]$ [28], and the four $\mathrm{p} K_{\mathrm{a}}$ values of spermine are: $\mathrm{p} K_{\mathrm{a} 1}=$ 10.86 (terminal [29] $\mathrm{NH}_{3}{ }^{+}$), $\mathrm{p} K_{\mathrm{a} 2}=10.05$ (terminal $\mathrm{NH}_{3}{ }^{+}$), $\mathrm{pK}$ a3 $=8.82$ (inner [29] $\mathrm{NH}_{2}{ }^{+}$), $\mathrm{pK} K_{\mathrm{a} 4}=7.95$ (inner $\mathrm{NH}_{2}+$ ) [potentiometric titration in $\mathrm{H}_{2} \mathrm{O}, 25^{\circ} \mathrm{C}$, ionic strength $(\mathrm{NaCl})$ 0.1] [30]. The cyclo-O ${ }_{8}-\mathrm{Na}^{+}$could react with alkaline $(\mathrm{pH} 7.9-8.0)$ buffered phenol [27] to disodium rhodizonate $\left(\mathrm{C}_{6} \mathrm{Na}_{2} \mathrm{O}_{6}\right)$, a known [31] oxidation product of $p$-benzoquinone, which in turn is an oxidation product of phenol [32]. Regardless of the chemical details, the commercial salmon sperm DNA (utilized in [5]) and calf thymus DNA preparations are devoid of cyclo- $\mathrm{O}_{8}-\mathrm{Na}^{+}$and spermine phosphate complexation, since the methods utilized for calf thymus [33] and salmon sperm [34] sodium deoxyribonucleate preparation (treatment with sodium dodecyl sulfate [33], high salt $(\mathrm{NaCl})$ treatment [33,34], repeated ethanol precipitation $[33,34])$ certainly remove the cyclooctaoxygen sodium-bridged spermine phosphate epigenetic shell.

Our findings have important consequences for the epigenetics [35] of eukaryotic in vivo DNA. We suggested [5] a model for a first epigenetic shell of in vivo DNA (Figure 3), based on the observed complexation of cyclo-Os- $\mathrm{Na}^{+}$and spermine phosphate to ssDNA. In our model (Figure 3A) the phosphate backbone of ssDNA binds one cyclo-Os- $\mathrm{Na}^{+}$pro three nucleotides, and this binary complex binds one spermine monophosphate to form a ternary epigenetic core of DNA. The monohydrogen phosphate bridges the cyclo-O $8-\mathrm{Na}^{+}$with the sperminium cation, and the cyclo- $\mathrm{O}_{8}-\mathrm{Na}^{+}$has an inverted alternating orientation (Figure 3A). Interestingly, the sperminium tetracation cannot bind alone to DNA in this model, since the distances [ $\left.d\left(N^{1}, N^{4}\right)=490 \mathrm{pm} ; d\left(N^{4}, N^{9}\right)=620 \mathrm{pm} ; d\left(N^{1}, N^{12}\right)=1,600 \mathrm{pm}\right]$ between the four ammonium nitrogens do not fit the intrastrand phosphate-phosphate distance of dsDNA (BDNA: $d \varnothing=700$ pm [36,37]; A-DNA: $d \varnothing=590-600$ pm [37-40]; Z-DNA: $d \varnothing=590$ pm (step pCp), $d \varnothing=600$ pm (step pGp) [40]). Therefore, it is quite remarkable that in our model for the first epigenetic shell of in vivo DNA (Figure 3A) a repeating unit is formed from cyclo-Os- $\mathrm{Na}^{+}$and spermine phosphate that perfectly fits both the triplet nature of the genetic code [41] and the repeating distance of the phosphate anion backbone of DNA.

Evidence for the correctness of this model results from the published investigation of spermine distribution in bovine lymphocytes [42]. The theoretical intracellular concentration of the sperminium phosphate/cyclo-O ${ }_{8}-\mathrm{Na}^{+}$complex required to cover all triplets of the dsDNA genome in a blood lymphocyte of Bos taurus was calculated as $13.81 \mathrm{mM}$ (see Methods 4.2.) [5]. The actual concentration of spermine was measured as $1.57 \pm 0.12$ ( $\mathrm{mM} \pm$ s.d.) [42]. Therefore, the genomic dsDNA coverage of $B$. taurus genome can be calculated as $2.62 \pm 0.50$ (\% \pm s.d.) (see Methods 4.2.) [5], since one unit of sperminium phosphate/cyclo-Os- $\mathrm{Na}^{+}$complex is assumed to cover three nucleotides. A good correlation was obtained when this value was compared to the proportion of protein-coding exons in B. taurus genome which was calculated as $2.58 \%$ (see Methods 4.2.). For comparison, the human genome contains $2.69 \%$ protein-coding exons (see Methods 4.6.). This pointed to complete coverage of actively transcribed gene regions in $B$. taurus interphase genome by the sperminium phosphate/cyclo-Os- $\mathrm{Na}^{+}$complex. Since spermine binds more strongly to GC-rich dsDNA (pBR322 plasmid) [42], it can be assumed that the sperminium phosphate/cyclo-Os- $\mathrm{Na}^{+}$complex binds preferentially to epigenetic, non-5-methylated $\mathrm{CpG}$ island hotspots [5] and is involved in epigenetic gene regulation [5].

In view of the important findings of Kirmes et al. [4] we were not aware of in 2015, that an interaction of eukaryotic chromatin DNA structure with atmospheric oxygen partial pressure takes place, 
we have to correct now previous postulations [5]. We concluded that the cyclooctaoxygen sodiumbridged spermine phosphate epigenetic shell is confined to both interphase relaxed euchromatin and mitotic condensed chromatin [5]. Since, under switching to hypoxic conditions eukaryotic cell chromatin gets highly condensed [4], accompanied by redistribution of the polyamine pool to the nucleus [4], the cyclooctaoxygen sodium-bridged spermine phosphate epigenetic shell can only be restricted to actively transcribed gene regions of eukaryotic 'open' euchromatin, excluding occupation of condensed chromatin. Hypoxia should largely prevent metabolic formation of cyclooctaoxygen. Both under hypoxic conditions and in the metaphase of mitosis, where spermine synthesis is highest [43], coincident with an extraordinary high condensation grade (15,000-20,000-fold) of metaphase chromatin [44], no or few cyclooctaoxygen should be involved in covering the highly condensed chromatin DNA. Here no or few discrimination between eu- and heterochromatin is made, and all eukaryotic chromatin DNA is complexed with spermine tetracation and spermidine trication (and, at small proportions, with putrescine and cadaverine dications).

This is supported by the published concentration of spermine in the metaphase chromatin of eukaryotic HeLa S3 cells [45]. The content of spermine in HeLa S3 cell metaphase chromatin was calculated as $135.9 \pm 16.1 \mathrm{pmol}$ spermine/82.84 zmol dsDNA, and $116.1 \pm 11.8$ pmol spermidine/82.84 zmol dsDNA (see Methods 4.3.) [5,45]. This corresponds to $1.64 \times 10^{9}$ molecules spermine pro one HeLa S3 cell dsDNA genome, and $1.40 \times 10^{9}$ molecules spermidine pro one HeLa S3 cell dsDNA genome. Since one spermine molecule is assumed to cover six base pairs (in the pure spermine form of A-DNA duplex [46] and Z-DNA duplex [47]), and one spermidine molecule is assumed to cover six base pairs (in the pure spermidine form of Z-DNA duplex [48,49]), this corresponds to a genomic coverage of $50.4 \%$ by the spermine tetracation, and of $43.0 \%$ by the spermidine trication. This accounts for $93.4 \%$ polyamine occupation of HeLa S3 cell dsDNA highly condensed metaphase chromatin by spermine and spermidine, calculated for six base pairs/polyamine unit. As one spermine molecule, in one special occasion, was found to cover four base pairs of an unique B-DNA [50], these values could be anticipated as being lower, since chromosomal DNA is predominantly in the B-DNA form.

Indirect control (we must here regretfully correct our postulations stated in [5], concerning this calculation) for this in vitro result is the published elemental phosphorus content $[w(\mathrm{P})$ in $\mathrm{mmol} / \mathrm{kg}$ dry weight] in female Mus musculus strain $\mathrm{C} 3 \mathrm{H} / \mathrm{HeJ}$ cryptal enterocytic mitotic (late anaphase/early telophase) chromatin [51]. The obtained in vivo value corresponds to a genomic dsDNA coverage (calculated for $6 \mathrm{bp} /$ polyamine) of $102.1 \%$ (100\% coverage is $5.88 \mathrm{bp} /$ polyamine), and a nuclear RNA coverage (calculated for 6 nucleotides/polyamine) of 159.5\%, by the spermine tetracation and spermidine trication (spermine/spermidine ratio 0.85) (see Methods 4.4.). This strongly points to a function of polyamine occupation for nuclear RNA, assuming 100\% coverage as 3.76 nucleotides/polyamine molecule. These results, both for dsDNA and nuclear RNA [hnRNA with pre-mRNAs, snRNA, snoRNA, RNase P, RNase MRP, various ncRNAs (lncRNA) and other nuclear RNAs] [52], are a logic consequence of the maximal condensation grade peaking in late anaphase/early telophase mammalian chromatin [53].

In summary, this reflects the high mitotic chromatin condensation grade and is confirming the results with hypoxia-induced chromatin condensation under coinciding polyamine pool nuclear translocation [4]. Interestingly, spermine and spermidine induced B-DNA to Z-DNA transition at epigenetic, non-5-methylated CpG island hotspots of prokaryotic plasmid DNA (pBR322 derivative) [54], but, in contrast, stabilized and condensed prokaryotic chromosomal B-DNA [55]. Z-DNA was found to be formed at $\mathrm{CpG}$ island transcriptional hotspots [56,57]. Regions near the transcription start site frequently contain sequence motifs favorable for forming Z-DNA, and formation of Z-DNA near the promoter region stimulates transcription [57]. All these observations point to the correctness of our model that the cyclooctaoxygen sodium-bridged spermine phosphate epigenetic shell is restricted to actively transcribed 
'hot spot' gene regions of eukaryotic 'open' euchromatin. Importantly, this epigenetic shell of eukaryotic 'open' euchromatin covers each strand of dsDNA separately, one at the positive strand, one at the negative strand (double occupation), whereas the highly condensed dsDNA structures bind one polyamine molecule directly at the double strand (single occupation) [46-50].

This is substantiated by the precise calculation of the apparent acid dissociation constant of the human genome DNA (see Methods 4.5.). The apparent (effective) $\mathrm{p} K_{\mathrm{a}, \mathrm{HG}}^{\prime}\left(25^{\circ} \mathrm{C}\right)=7.18$ of the haploid human genome was calculated (Figure 12A) according to the method of Katchalsky \& Gillis [58], as based on the theoretical considerations of Kuhn \& Kuhn [59]. The hypothetical intranuclear pHDNA $=1.66$, mediated by $H$. sapiens haploid interphase genome dsDNA without any neutralizing shell, can be calculated (Figure 12B) (see Methods 4.6.). Assuming one spermine molecule covering four base pairs (single occupation) of B-DNA [50], and correcting for actively transcribed gene regions of $H$. sapiens genome, the hypothetical intranuclear micro-pH [60] surrounding $H$. sapiens haploid interphase euchromatin when covered (single quartet occupation) by the spermine tetracation alone can be calculated pHDNA/spermine $=7.43$ (see Methods 4.6.). For the diploid dsDNA genome, after completed S phase during interphase, the $\mathrm{pHDNA} / \mathrm{spermine}$ is identical. The theoretical intranuclear micro-pH surrounding H. sapiens haploid interphase euchromatin when covered (double triplet occupation) by the sperminium phosphate/cyclooctaoxygen sodium complex can be calculated $\mathrm{pHDNA} / \mathrm{shell}=7.42$ (see Methods 4.7.). For the diploid dsDNA genome, after completed $\mathrm{S}$ phase during interphase, the $\mathrm{pHDNA} / \mathrm{shell}$ is identical.

We also elaborated a model for selenium (as hydrogen selenite, $\mathrm{HSeO}_{3^{-}}$, at physiological $\mathrm{pH}$ 7.4) protection of DNA (Figure 3B) [5]. Selenium, the element of the moon [61], was discovered by Jöns Jacob Berzelius (1779-1848) in 1817 and was named by him in honor of the Greek goddess of the moon Selene ( $\sigma \varepsilon \lambda \eta \dot{v \eta}$ ) [62]. Selenium is essential to mammalian physiology at nutritional levels, but supraphysiological intake of selenium is known to be toxic for mammals $[5,7]$. Sodium selenite $\left(\mathrm{Na}_{2} \mathrm{SeO}_{3}\right)$, as hydrogen selenite $\mathrm{HSeO}_{3}{ }^{-}$at $\mathrm{pH} 7.0$ (selenious acid $\mathrm{H}_{2} \mathrm{SeO}_{3}: \mathrm{p} K_{\mathrm{a} 1}=2.62, \mathrm{pK}_{\mathrm{a} 2}=8.32$ [63]), binds to calf thymus genomic B-DNA at pH 7.0 [64], and to Saccharomyces cerevisiae A-RNA at pH 7.0 [65]. Selenium has the ability to protect DNA from noxious influences (oxidative stress, radiation, cytotoxic agents) [5], and is essential to genomic stability $[5,7,66,67]$, but the exact molecular biological basis for these phenomena is unknown. If in our model of a first epigenetic shell of in vivo DNA (Figure 3A) the monohydrogen phosphate is replaced by hydrogen selenite (Figure 3B), an epigenetic explanation for the interaction of selenium with eukaryotic in vivo DNA could be given. This model may account for, at least some of, the well-known bimodal, protective and toxic, in vivo effects exerted by selenium onto mammalian physiology [5,7]. A moderate substitution pattern of hydrogen selenite for monohydrogen phosphate would be essential, but if the displacement ratio $\mathrm{HSeO}_{3}-\mathrm{HPO}_{4}{ }^{2-}$ exceeds a certain tolerance level, the epigenetic equilibrium should collapse. The extraordinary high, both acute and chronic, mammalian toxicity of sodium selenite $\left(\mathrm{Na}_{2} \mathrm{SeO}_{3}\right)$ [68] should be due, at least in part, to direct detrimental effects of supraphysiological levels of hydrogen selenite $\mathrm{HSeO}_{3}{ }^{-}$on mammalian chromosomal DNA integrity and regulation of genome expression. In fact, $\mathrm{Na}_{2} \mathrm{SeO}_{3}$ is a violent poison with a lethal dose $50 \%$ (LD50, orally in rats, $7 \mathrm{mg} / \mathrm{kg}[69]$ ), being lower than the $\mathrm{LD}_{50}$ of sodium cyanide ( $\mathrm{NaCN}$ ) (LD50, orally in rats, $15 \mathrm{mg} / \mathrm{kg}$ [70]).

Assuming an essential biological function for the cyclooctaoxygen sodium-bridged spermine phosphate and selenite epigenetic shell, we searched for substances able to selectively destroy this epigenetic protection structure, and tested the total herbicide glyphosate, $\mathrm{N}$-(phosphonomethyl)glycine (ROUNDUP®, Monsanto), and its major environmental metabolite (aminomethyl)phosphonic acid (AMPA) [71] on the cyclo-Os- $\mathrm{Na}^{+}$complex contained in RC. Glyphosate was chosen because it represents the top selling total herbicide worldwide [72], and RC was selected because of its highest molar cyclo-Os$\mathrm{Na}^{+}$content in the complex series NC, dNC, and RC (Figure 4) [5]. Glyphosate and AMPA show chemical 
properties which might predispose them for destruction of cyclooctaoxygen in general. Glyphosate and AMPA are very hydrophilic and amphoteric, and their phosphonate moieties could be suitable to interact with cyclo-Os- $\mathrm{Na}^{+}$. We could show unequivocally that glyphosate and AMPA indeed selectively destroy the cyclo-Os- $\mathrm{Na}^{+}$complex contained in RC (see Methods 4.8., 4.9. and 4.10.) (Figure 7, 8, 9 and 10). We therefore conclude that glyphosate and the major environmental glyphosate metabolite AMPA [71] also destroy the cyclooctaoxygen sodium-bridged spermine phosphate and selenite epigenetic shell of human euchromatin, because destruction of cyclooctaoxygen is sufficient to bring this essential protection shield of human euchromatin into collateral epigenetic collapse.

To get support for the selectivity of AMPA as an epigenetic poison, the affinity of AMPA towards human mitochondrial -aminobutyric acid transaminase (ABAT) [25], and to wild-type human liver peroxisomal alanine:glyoxylate aminotransferase (AGT) [26], was determined (see Methods 4.11. and 4.12.). ABAT represents also a -alanine transaminase [25], and both enzymes were selected because of the structural similarity between AMPA and -alanine/L-alanine. AMPA showed essentially no affinity to ABAT, but was very showly catabolized by AGT (Figure 11A). This latter result is of interest, since the product of the half-transamination of AMPA by AGT is phosphonoformaldehyde which can be oxidized (peroxisomal glycolate oxidase, cytoplasmic lactate dehydrogenase [73]) to phosphonoformic acid (phosphonoformate, forscarnet) (Figure 11B). Foscarnet represents a well-known inhibitor of mammalian $[74,75]$ and viral $[74,75]$ DNA-dependent DNA polymerases. Eukaryotic DNA polymerase is crucially involved in chromosome maintenance, DNA repair and recombination, transcriptional silencing, checkpoint activation, and telomere length maintenance [76]. Mammalian DNA polymerase is potently inhibited by foscarnet [74,75]. Therefore, the low-affinity half-transamination of AMPA by AGT, the ratelimiting step leading to foscarnet, could negatively influence human chromosome maintenance, DNA damage repair, and telomere length preservation, mediated by the AMPA catabolite foscarnet inhibition of DNA polymerase. This enzymatic catabolism provides an additional, minor mechanism of destabilization and impairment of eukaryotic chromosomal DNA indirectly induced by the environmental glyphosate metabolite AMPA.

\section{Materials and Methods \\ 4.1. Materials}

The following materials were utilized: $\mathrm{NC}\left(\mathrm{C}_{9} \mathrm{H}_{14} \mathrm{ClN}_{3} \mathrm{O}_{5} \times 2 \mathrm{ClNaO}_{8} \times 2 \mathrm{H}_{2} \mathrm{O} \times 1 / 2 \mathrm{C}_{3} \mathrm{H}_{6} \mathrm{O}\right)=$ [tetrakis( -D-cytidin- $\mathrm{N}^{3}$-ium)(octoxocane- $\left.{ }^{4} \mathrm{O}^{1}, \mathrm{O}^{3}, \mathrm{O}^{5}, \mathrm{O}^{7}\right)$ ] $\operatorname{sodium}\left(5^{+}\right)$pentachloride dihydrate hemiacetonate $(M=1370.22 \mathrm{~g} / \mathrm{mol})[5] ; \mathbf{R C}\left(\mathrm{C}_{9} \mathrm{H}_{14} \mathrm{ClN}_{3} \mathrm{O}_{5} \times 2 \mathrm{HClNa}_{2} \mathrm{O}_{17} \times 1 / 4 \mathrm{C}_{3} \mathrm{H}_{6} \mathrm{O}\right)=$-D-cytidine hydrochloride - -chloro( -hydroxy)bis(octoxocane- $\left.{ }^{4} \mathrm{O}^{1}, \mathrm{O}^{3}, \mathrm{O}^{5}, \mathrm{O}^{7}\right)$ disodium $(1: 2) \times 0.25$ acetone $(\mathrm{M}=$ $1003.06 \mathrm{~g} / \mathrm{mol})$ [5]; potassium iodide (KI) puriss. p.a., reag. ISO, reag. Ph.Eur., $w(\mathrm{~m} / \mathrm{m}) \geq 99.5 \%(M=166.00$ $\mathrm{g} / \mathrm{mol}$ ) [Sigma-Aldrich Corp., St. Louis, MO, USA; pH 6.0-9.0 [20 ${ }^{\circ} \mathrm{C}, 5 \%(\mathrm{~m} / \mathrm{m})$ in $\mathrm{H}_{2} \mathrm{O}$ ], loss on drying $\leq$ $0.2 \%\left(105^{\circ} \mathrm{C}\right)$, total nitrogen $(\mathrm{N}) \leq 0.001 \%$, heavy metals $(\mathrm{as} \mathrm{Pb}) \leq 0.0005 \%$, iodate $\left(\mathrm{IO}_{3^{-}}\right) \leq 2 \mathrm{mg} / \mathrm{kg}$; starch puriss. p.a., from potato, reag. ISO, reag. Ph.Eur., soluble [Sigma-Aldrich Corp., St. Louis, MO, USA; pH 6.0-7.5, loss on drying $\leq 13 \%\left(105{ }^{\circ} \mathrm{C}\right)$, sulfated ash $\leq 0.5 \%$, substances reducing Fehling solution (as maltose) $\leq 0.7 \%$ ]; (aminomethyl)phosphonic acid (AMPA) $\left(\mathrm{CH}_{6} \mathrm{NO}_{3} \mathrm{P}, M=111.04 \mathrm{~g} / \mathrm{mol}\right.$ ) [Sigma-Aldrich Corp., St. Louis, MO, USA, Lot: MKBX8824V; $w(\mathrm{~m} / \mathrm{m})=98.5 \%$ (titration), carbon (C) $10.9 \%$, nitrogen (N) $12.6 \%$ ]; $N$-(phosphonomethyl)glycine (glyphosate) $\left(\mathrm{C}_{3} \mathrm{H}_{8} \mathrm{NO}_{5} \mathrm{P}, \mathrm{M}=169.07 \mathrm{~g} / \mathrm{mol}\right.$ ) [Sigma-Aldrich Corp., St. Louis, MO, USA, Lot: MKBX1937V; $w(n / n)>99 \%$ (TLC), carbon (C) 21.3\%, nitrogen (N) 8.2\%, mp 230 ${ }^{\circ} \mathrm{C}$ (dec.)]; deuterated chloroform $\left(\mathrm{CDCl}_{3}\right)$ [euriso-top ${ }^{\circledR}$, Saint Aubin cedex, France, Lot: D007H, W2631; $99.80 \% \mathrm{D}, \mathrm{H}_{2} \mathrm{O}<0.01 \%$, stored over molecular sieve $3 \AA \AA$; molecular sieve $3 \AA$ ( $0.3 \mathrm{~nm}$, zeolithe, metalaluminosilicate) [AppliChem GmbH, Darmstadt, Germany; Lot: 5H002478; water absorbency $\geq 20 \%$ ( 24 h, $80 \%$ humidity)]; elemental iodine $\mathrm{I}_{2}(M=253.81 \mathrm{~g} / \mathrm{mol})$ (iodum resublimatum Ph.Eur. 7.0) [Caesar \& Loretz (Caelo) $\mathrm{GmbH}$, Hilden, Germany, Lot: 122890; $w(\mathrm{~m} / \mathrm{m})=99.9 \%$ (titration), non-volatile matter $\leq$ 
0.1\%, $\mathrm{Br}^{-}$and $\mathrm{Cl}^{-} \leq 250 \mathrm{ppm}$ ]. L-Ascorbic acid (vitamin C) Ph.Eur. $7.0(\mathrm{M}=176.12 \mathrm{~g} / \mathrm{mol})$ was purchased from a local pharmacy store (Friedens-Apotheke, München-Trudering, Germany). Glyphosate monosodium salt $\left(\mathrm{C}_{3} \mathrm{H}_{7} \mathrm{NNaO}_{5} \mathrm{P}, M=191.05 \mathrm{~g} / \mathrm{mol}\right)$ was purchased in form of ROUNDUP® GRAN 15,5 $\mathrm{g}$ granules [Monsanto Europe S.A., Antwerp, Belgium, Lot: T346 (prod. date 12/12/2011); contains 475 g/kg glyphosate-Na, $w_{\text {glyphosate-Na }}(\mathrm{m} / \mathrm{m})=47.5 \%$, inert carrier material $33.5 \%$, water and excipients $19 \%$ ].

\subsection{Calculation of the Genomic Coverage by the Cyclooctaoxygen Sodium-Bridged Spermine Phosphate Epigenetic} Shell of Interphase DNA in Bovine Lymphocytes

The average volume of human lymphocytes was taken as $206 \mathrm{fl}$ (femtoliter) [77]. The average volume of bovine lymphocytes was taken as $214 \mathrm{fl}$ (femtoliter) after introducing a technical correction factor of $f=0.834$ [78]. The reference genome size of Bos taurus (Hereford breed) was taken as 2,670,139,648 bp (RefSeq assembly accession number GCF_000003055.6) [79]. This genome showed 41.89\% GC content [79]. The theoretical intracellular concentration of the sperminium phosphate/cyclo- $\mathrm{O}_{8}-\mathrm{Na}^{+}$ complex required to cover all triplets of the dsDNA genome in a blood lymphocyte of $B$. taurus was calculated: $\left[214 \mathrm{fl} \times 6.022140857 \times 10^{23} \mathrm{~mol}^{-1}\right]^{-1} \times 2,670,139,648 \times 2 \times 3^{-1}=7.7597 \mathrm{pM} \times 1,780,093,099=13.8127$ $\mathrm{mM}$. The coverage of B. taurus genome by the sperminium phosphate/cyclo-Os- $\mathrm{Na}^{+}$complex was calculated (mean \pm s.d.: $2.6208 \pm 0.4953 \%$ ) from the published [42] fractions of spermine bound to dsDNA: $421 \mu \mathrm{M} \times\left[13.8127 \mathrm{mM}^{-1}=3.0479 \%\right.$ (in presence of $2 \mathrm{mM} \mathrm{Mg}^{2+}$ and $100 \mathrm{mM} \mathrm{K}^{+}$), $287 \mu \mathrm{M} \times[13.8127 \mathrm{mM}]^{-1}=$ $2.0778 \%\left(2 \mathrm{mM} \mathrm{Mg}^{2+}, 150 \mathrm{mM} \mathrm{K}^{+}\right)$, and $378 \mu \mathrm{M} \times\left[13.8127 \mathrm{mM}^{-1}=2.7366 \%\left(10 \mathrm{mM} \mathrm{Mg}^{2+}, 100 \mathrm{mM} \mathrm{K}^{+}\right)\right.$. The number of base pairs for the number of protein-coding exons in B. taurus genome $(49,107)[79]$ was calculated with the median of amino acid residues/gene (468) [79]: 49,107 $\times 3 \mathrm{bp} \times 468=68,946,228 \mathrm{bp}$ ( $2.5821 \%$ of B. taurus genome). The GC content of E. coli-derived pBR322 plasmid covalently closed circular dsDNA (GenBank accession number J01749.1) was calculated from its sequence as 53.75\%.

\subsection{Calculation of the Spermine Coverage of Highly Condensed Mitotic Metaphase DNA in HeLa S3 Cells}

The average effective molecular mass of $\mathrm{dGp} / \mathrm{dCp}$ was calculated as $M=309.19 \mathrm{~g} / \mathrm{mol}$, of $\mathrm{dAp} / \mathrm{dTp}$ as $M=308.70 \mathrm{~g} / \mathrm{mol}$. The reference Homo sapiens genome size was taken as 3,238,442,024 bp (RefSeq assembly accession number GCF_000001405.35) [80]. This genome showed 41.46\% GC content [80]. The molecular mass of this human genome dsDNA was calculated: $(0.4146 \times 309.19 \mathrm{~g} / \mathrm{mol})+(0.5854$ $\times 308.70 \mathrm{~g} / \mathrm{mol}) \times(3,238,442,024 \mathrm{bp} \times 2)=2.000730 \times 10^{12} \mathrm{~g} / \mathrm{mol}$. The HeLa cell genome [81] was anticipated as 76 chromosomes (hypertriploid) +22 abnormal chromosomes [81,82]. The chromosomal DNA size of HeLa metaphase chromatin dsDNA was calculated as $19,539,129,390$ bp with $M=1.207127414 \times 10^{13}$ $\mathrm{g} / \mathrm{mol}$ from published karyotyping [82]. The content of spermine in HeLa S3 cell metaphase chromatin was taken as $135.9 \pm 16.1 \mathrm{pmol} / \mu \mathrm{g}$ DNA [45]. This was transformed into $135.9 \pm 16.1 \mathrm{p}$ (ico)mol spermine/82.84129651 $\mathrm{z}$ (epto)mol dsDNA $=1,640,486,155$ (molecules spermine/dsDNA). Since one spermine molecule is assumed to cover six bp (in the pure spermine form of A-DNA duplex [46] and ZDNA duplex [47]), this corresponds to a coverage of 1,640,486,155 $\times 6 \times[19,539,129,390]^{-1}=50.3754 \%$ of HeLa S3 cell metaphase chromatin dsDNA genome by spermine. The content of spermidine in HeLa S3 cell metaphase chromatin was taken as $116.1 \pm 11.8 \mathrm{pmol} / \mu \mathrm{g}$ DNA [45]. This was transformed into $116.1 \pm$ $11.8 \mathrm{p}$ (ico)mol spermidine/82.84129651 $\mathrm{z}$ (epto)mol dsDNA $=1,401,474,927$ (molecules spermidine/dsDNA). Since one spermidine molecule is assumed to cover six bp (in the pure spermidine form of Z-DNA duplex [48,49]), this corresponds to a coverage of 1,401,474,927 $\times 6 \times[19,539,129,390]^{-1}=$ $43.0359 \%$ of HeLa S3 cell metaphase chromatin dsDNA genome by spermidine. Taken together, the polyamine (spermine/spermidine ratio 1.17) coverage of HeLa S3 cell metaphase chromatin dsDNA is $50.3754 \%+43.0359 \%=93.4113 \%$.

4.4. Calculation of the Polyamine Coverage of Maximally Condensed Mitotic Late Anaphase/Early Telophase DNA in Murine Cryptal Enterocytes 
The phosphorus (P) content of female Mus musculus strain C3H/HeJ cryptal enterocytic mitotic (late anaphase/early telophase) chromatin was taken as $298.5 \pm 17.3 \mathrm{mmol}(\mathrm{P}) / \mathrm{kg}$ [51]. The average effective molecular mass of one nucleotide unit (dGp/dCp and $\mathrm{dAp} / \mathrm{dTp}$ ) in $M$. musculus $\mathrm{C} 3 \mathrm{H} / \mathrm{HeJ}$ genome $(2,701,131,316 \mathrm{bp})$ [83] was calculated with the GC content of $42.82 \%$ [83]: $M=308.91 \mathrm{~g} / \mathrm{mol}$. With the formula $w(\mathrm{P})=(n \mathrm{P}) \times M^{-1}(n \mathrm{P}$, number of $\mathrm{P}$ atoms pro formula unit; $M$, molecular weight of formula unit) the phosphorus content $w(\mathrm{P})$ of murine mitotic chromatin was calculated: $3,237.19 \mathrm{mmol}(\mathrm{P}) / \mathrm{kg}$ (free dsDNA). The value for complete complexation with one spermine tetracation/six nucleotides is $2,912.86 \mathrm{mmol}(\mathrm{P}) / \mathrm{kg}$ (spermine tetracation-complexed ssDNA), and for complete complexation with one spermidine trication/six nucleotides is $2,997.41 \mathrm{mmol}(\mathrm{P}) / \mathrm{kg}$ (spermidine trication-complexed ssDNA). Taking the arithmetic mean of the published $[42,84]$ spermine/spermidine ratio 0.85 , bound to rat liver DNA and RNA (2 mM Mg$\left.{ }^{2+}, 150 \mathrm{mM} \mathrm{K}^{+}\right)$[42], or in Sprague-Dawley rat liver nuclei [84], the theoretical value for complete complexation is $\left\{(2,912.86 \times 0.85)+[(2,997.41 \times(2-0.85)]\} \times 2^{-1}=2,961.48(\mathrm{P}) / \mathrm{kg}\right.$ (spermine tetracation/spermidine trication-complexed ssDNA). Phosphatidylcholine in its dipalmitoyl (C16:0) lipid composition $(M=734.04 \mathrm{~g} / \mathrm{mol})$ is the main constituent $(60.8 \pm 1.3 \%)$ of the phospholipid fraction in rat liver chromatin [85]. This molecular weight was corrected to an average effective molecular mass $M=765.03 \mathrm{~g} / \mathrm{mol}$, based on the fractions [85] and lipid compositions [85] of phospholipids (phosphatidylcholine, phosphatidylethanolamine, phosphatidylserine, phosphatidylinositol, sphingomyelin) in Sprague-Dawley rat liver chromatin, to yield the reference value for the (P) content of phospholipid 1,307.13 mmol (P)/kg. The fractions of DNA $(32.0 \pm 4.1 \%)$, RNA $(5.1 \pm 1.6 \%)$, protein $(62.6 \pm$ $3.8 \%)$, and phospholipid $(0.2 \pm 0.1 \%)$ in Sprague-Dawley rat liver chromatin were taken as published [85], and applied on the murine mitotic chromatin nucleic acids (DNA + RNA). The published [51] value was corrected for the chromatin-bound cation $\left(\mathrm{Na}^{+}, \mathrm{K}^{+}, \mathrm{Mg}^{2+}, \mathrm{Ca}^{2+}\right)$ [51], protein and phospholipid [85] content: $\left\{\left[841.0 \mathrm{mmol}\left(\mathrm{Na}^{+}, \mathrm{K}^{+}, \mathrm{Mg}^{2+}, \mathrm{Ca}^{2+}\right) / \mathrm{kg}+298.5 \mathrm{mmol}(\mathrm{P}) / \mathrm{kg}\right] \times 100 \times 37.1^{-1}\right\}+\left[0.2 \times 100^{-1} \times 1,307.13 \mathrm{mmol}\right.$ $(\mathrm{P}) / \mathrm{kg}]=3,074.04 \mathrm{mmol}(\mathrm{P}) / \mathrm{kg}$ (ssDNA + ssRNA) in mitotic late anaphase/early telophase chromatin. The six nucleotide coverage (ssDNA + ssRNA) by the polyammonium cations was calculated: $(3,237.19-$ $3,074.04) \times(3,237.19-2,961.48)^{-1} \times 100 \%=59.1745 \%$. The genomic dsDNA six bp coverage by the polyammonium cations, corrected for the nuclear RNA content, was calculated: $59.1745 \% \times\left(32.0 \times 37.1^{-1}\right)$ $\times 2=102.0800 \%$. This corresponds to a coverage of $5.8777 \mathrm{bp}$ murine cryptal enterocytic mitotic (late anaphase/early telophase) chromatin dsDNA by one polyammonium cation (spermine/spermidine ratio 0.85). The six nucleotide coverage of nuclear RNA by the polyammonium cations was calculated: $59.1745 \%-\left(102.0800 \% \times 2^{-1}\right)=8.1345 \%$, corresponding to a relative six nucleotide coverage of nuclear RNA: $8.1345 \times(5.1)^{-1} \times 100 \%=159.5000 \%$. This corresponds to a coverage of 3.7618 nucleotides of nuclear RNA by one polyammonium cation (spermine/spermidine ratio 0.85 ).

\subsection{Calculation of the Apparent Acid Dissociation Constant of the Human Genome DNA}

The intrinsic $\mathrm{p} K_{\mathrm{a}}$ of one isolated phosphodiester of DNA is 1.29 , this is the $\mathrm{p} K_{\mathrm{a}}\left(25^{\circ} \mathrm{C}\right)$ of dimethyl phosphate [86]. The reference $H$. sapiens genome size was taken as 3,238,442,024 bp (RefSeq assembly accession number GCF_000001405.35) [80]. The apparent (effective) $\mathrm{p} K_{a, \mathrm{HG}}^{\prime}\left(25^{\circ} \mathrm{C}\right)=7.1849$ of the haploid human genome was calculated (Figure 12A) according to the method of Katchalsky \& Gillis [58], as based on the theoretical considerations of Kuhn $\mathcal{E}$ Kuhn [59]. The length rise of one B-DNA repeating unit (helix rise/bp) in solution (in the crystal: $0.336 \mathrm{~nm}[87,88])$ was taken as: $b=0.334 \times 10^{-7} \mathrm{~cm}(0.334 \pm 0.01 \mathrm{~nm}[87])$. The $h_{0}$ was calculated by: $0.334 \mathrm{~nm} \times 3,238,442,024=1.08163964 \mathrm{~m}$ (= theoretical length of $H$. sapiens dsDNA haploid genome as linear thread). The $h$ was calculated by: $0.5 \times(0.334 \mathrm{~nm}+0.5798 \mathrm{~nm}) \times$ $3,238,442,024=1.47964416 \mathrm{~m}$ (theoretical length of half-neutralized $H$. sapiens dsDNA haploid genome as linear thread) (Figure 12A). The $0.5798 \mathrm{~nm}$ pitch in one relaxed (fully neutralized) dsDNA repeating unit was calculated as statistic arithmetic mean $d \varnothing=579.80 \mathrm{pm}$ from the interphosphorus distance $d\left(5^{\prime}-P, 5^{\prime}-P\right)$ $=739.25 \pm 14.37 \mathrm{pm}(d \pm$ s.d.; $n=4)$ in the fully ionized single-stranded hexanucleotide $\mathrm{d}(\mathrm{ApApApApApAp)}$ [molecular modeling software: ACD/Chem Sketch version 12.01 with integrated 
ACD/3D Viewer (Advanced Chemistry Development, Inc., Toronto, Ontario, Canada), processed with Mercury 3.1 version 3.1.1 (The Cambridge Crystallographic Data Centre, Cambridge, United Kingdom)], minus the typical phosphorus-oxygen distance $d(P, O)=159.45 \mathrm{pm}[89]$, by the formula: $d \varnothing=739.25 \mathrm{pm}-$ $159.45 \mathrm{pm}=579.80 \mathrm{pm}$.

\subsection{Calculation of the Hypothetical Intranuclear Micro-pH Mediated by Single Spermine Occupation of Human Interphase Euchromatin}

The reference $H$. sapiens genome size was taken as 3,238,442,024 bp (RefSeq assembly accession number GCF_000001405.35) [80]. The number of base pairs for the number of protein-coding exons in $H$. sapiens genome $(59,911)$ [80] was calculated with the median of amino acid residues/gene (484) [80]: 59,911 $\times 3 \mathrm{bp} \times 484=86,990,772 \mathrm{bp}(2.6862 \%$ of $H$. sapiens genome). The intrinsic $\mathrm{pH}$ of $H$. sapiens haploid interphase genome was calculated with the volume of a human blood lymphocyte interphase nucleus of $40.2 \pm 2.0 \mathrm{fl}$ (femtoliter) [78]. Because H. sapiens dsDNA haploid genome is to be treated as a weak acid $\left[\mathrm{pK}_{\mathrm{a}, \mathrm{HG}}^{\prime}\left(25^{\circ} \mathrm{C}\right)=7.1849\right]$, the hypothetical nuclear $\mathrm{pHDNA}=1.6642$, mediated by $H$. sapiens haploid interphase genome dsDNA, can be calculated (Figure 12B). The concentration CDNA was calculated as: [1 genome $\left.\times\left(6.022140857 \times 10^{23} \mathrm{~mol}^{-1}\right)^{-1}\right] \times\left(40.2 \mathrm{fl}^{-1}=41.3069 \mu \mathrm{M}\right.$. This concentration was multiplied by the number of phosphodiester moieties in dsDNA $(3,238,442,024 \times 2)$ and corrected for actively transcribed gene regions of $H$. sapiens genome $(2.6862 \%)$. The four $\mathrm{p} K_{\mathrm{a}}$ values $\left( \pm\right.$ s.d.) of spermine $\mathrm{p} K_{\mathrm{a} 1}=10.86 \pm 0.06$, $\mathrm{p} K_{\mathrm{a} 2}=10.05 \pm 0.01, \mathrm{p} K_{\mathrm{a} 3}=8.82 \pm 0.01, \mathrm{p} K_{\mathrm{a} 4}=7.95 \pm 0.01$ [potentiometric titration in $\mathrm{H}_{2} \mathrm{O}, 25{ }^{\circ} \mathrm{C}$, ionic strength $(\mathrm{NaCl}) 0.1$ ] [30] give the apparent (effective) $\mathrm{p} K^{\prime}$ spermine $\left(25^{\circ} \mathrm{C}\right)=9.42 \pm 0.02$ (mean \pm s.d.). Because the hypothetical nuclear concentration of spermine tetracation covering B-DNA is one quarter of $C \mathrm{DNA}$, if we assume one spermine molecule covering four base pairs (single occupation) of B-DNA [50], and correcting for actively transcribed gene regions of $H$. sapiens genome $(2.6862 \%)$, the $\mathrm{pH}_{\text {spermine }}=13.1867$ can be calculated (Figure 12B). Therefore, the hypothetical intranuclear micro-pH surrounding $H$. sapiens haploid interphase euchromatin when covered (single quartet occupation) by the spermine tetracation can be calculated as: $\mathrm{pHDNA} / \mathrm{spermine}=0.5 \times(1.6642+13.1867)=7.4255$. For the diploid dsDNA genome, after completed S phase during interphase, the hypothetical micro-pH surrounding $H$. sapiens diploid interphase euchromatin when covered (single quartet occupation) by the spermine tetracation is, again, pHDNA/spermine $=7.4255$.

\subsection{Calculation of the Theoretical Intranuclear Micro-pH Mediated by Sperminium Phosphate/Cyclooctaoxygen} Sodium Complex Occupation of Human Interphase Euchromatin

The apparent $\mathrm{pK}$ 'spermine was corrected for the monohydrogen phosphate complexation to get the apparent (effective) $\mathrm{p} K^{\prime}$ shell of the sperminium phosphate/cyclooctaoxygen sodium complex epigenetic shell. Ortho-phosphoric acid $\mathrm{H}_{3} \mathrm{PO}_{4}$ shows the $\mathrm{p} K_{\mathrm{a} 1}=2.161, \mathrm{p} K_{\mathrm{a} 2}=7.207$, and $\mathrm{p} K_{\mathrm{a} 3}=12.325$ at $25{ }^{\circ} \mathrm{C}$ [90]. Therefore, the $\mathrm{p} K^{\prime}$ spermine is to be corrected for the monohydrogen phosphate of the epigenetic shell: $\mathrm{p} K^{\prime}$ shell $=[9.42+(\{[(2.161+7.207) \times 0.5]+12.325\} \times 0.5)] \times 0.5=8.96225$. Because the theoretical nuclear concentration of the sperminium phosphate/cyclooctaoxygen sodium complex covering dsDNA is twothird of CDNA, when we assume one epigenetic complex molecule covering three base pairs on both strands of dsDNA (double occupation), and correcting for actively transcribed gene regions of $H$. sapiens genome $(2.6862 \%)$, the $\mathrm{pH}_{\text {shell }}=13.1708$ (Figure $12 \mathrm{~B}$ ). Therefore, the theoretical intranuclear micro- $\mathrm{pH}$ surrounding $\mathrm{H}$. sapiens haploid interphase euchromatin when covered (double triplet occupation) by the sperminium phosphate/cyclooctaoxygen sodium complex can be calculated as: $\mathrm{pHDNA} /$ shell $=0.5 \times(1.6642+$ $13.1708)=7.4175$. For the diploid dsDNA genome, after completed $S$ phase during interphase, the theoretical micro-pH surrounding $H$. sapiens diploid interphase euchromatin when covered (double triplet occupation) by the sperminium phosphate/cyclooctaoxygen sodium complex is, again, $\mathrm{pHDNA} /$ shell $=$ 7.4175 . 
4.8. Color Assay for Cyclo-Os-Na+ Contained in $\mathrm{RC}$ - Destruction of $\mathrm{Cyclo}_{8} \mathrm{O}_{8}-\mathrm{Na}^{+}$by the Glyphosate Metabolite (Aminomethyl)phosphonic Acid

Stock preparations were: $\mathrm{KI}\left(52 \mathrm{mg} \mathrm{KI}\right.$ in 2,000 $\left.\mu \mathrm{l} \mathrm{H} \mathrm{H}_{2} \mathrm{O}\right)(\mathbf{1}), \mathrm{KI}+$ starch $(52 \mathrm{mg} \mathrm{KI}+18 \mathrm{mg}$ starch in 2,000 $\left.\mu \mathrm{l} \mathrm{H} \mathrm{H}_{2} \mathrm{O}\right)(2), \quad \mathrm{RC}+\mathrm{KI}\left(34 \mathrm{mg} \mathbf{R C}+52 \mathrm{mg} \mathrm{KI}\right.$ in 2,000 $\left.\mu \mathrm{l} \mathrm{H} \mathrm{H}_{2} \mathrm{O}\right)(3), \mathbf{R C}+\mathrm{KI}+\mathrm{AMPA}(34 \mathrm{mg} \mathbf{R C}+52$ mg KI + 22 mg AMPA in 2,000 $\left.\mu \mathrm{l} \mathrm{H} \mathrm{H}_{2} \mathrm{O}\right)(4), \mathrm{RC}+\mathrm{KI}+\operatorname{starch}(34 \mathrm{mg} \mathbf{R C}+52 \mathrm{mg} \mathrm{KI}+18 \mathrm{mg}$ starch in 2,000 $\mu \mathrm{l} \mathrm{H}_{2} \mathrm{O}$ ) (5), $\mathbf{R C}+\mathrm{KI}+$ starch + AMPA (34 mg RC + $52 \mathrm{mg} \mathrm{KI}+18 \mathrm{mg}$ starch + $22 \mathrm{mg}$ AMPA in 2,000 $\mu \mathrm{l}$ $\mathrm{H}_{2} \mathrm{O}$ ) (6). The concentrations in solution were: RC, $16.9481 \mathrm{mM}$ (with cyclo-Os- $\mathrm{Na}^{+}, 67.7924 \mathrm{mM}$ ); KI, $156.6265 \mathrm{mM}$; AMPA, $99.0634 \mathrm{mM}$.

The stock solutions were incubated at room temperature (RT, $\vartheta=14.0^{\circ} \mathrm{C}$ ) for $30 \mathrm{~min}$, then at elevated temperature $\left(\vartheta=25.2^{\circ} \mathrm{C}\right)$ for $2 \mathrm{~min}$, after which time the first photograph series (Figure 7) was taken. The solutions were then incubated at elevated temperature for $48 \mathrm{~min}$, after which time the second photograph (Figure 7) series was taken. The solutions were further incubated at RT for $14 \mathrm{~h}$. Afterwards, both RC + KI (3) and RC + KI + AMPA (4) were mixed with 1,000 $\mu$ deuterated chloroform $\left(\mathrm{CDCl}_{3}\right)$, and extracted by shaking. Concomitantly, RC + KI + starch (5) and RC + KI + starch + AMPA (6) were both mixed with $8 \mathrm{mg}$ of solid L-ascorbic acid (concentration of L-ascorbic acid in solution $22.7118 \mathrm{mM}$ ). The solutions were succeedingly incubated at elevated temperature for $15 \mathrm{~min}$, after which time the third photograph series (Figure 7) was taken.

4.9. Control Color Assay for Potential Reduction of Elemental Iodine by the Glyphosate Metabolite (Aminomethyl)phosphonic Acid

Stock preparations were: blank without AMPA $\left(1,000 \mu \mathrm{l} \mathrm{H}_{2} \mathrm{O}\right)$, AMPA stock solution $(34 \mathrm{mg}$ AMPA in 1,000 $\left.\mu \mathrm{l} \mathrm{H}_{2} \mathrm{O}\right)$, and two iodine stock solutions [each $80 \mathrm{mg}$ elemental iodine in 2,000 $\mu \mathrm{l} 90 \%(v / v)$ aqueous ethanol]. The stock preparations were incubated at room temperature (RT, $\vartheta=14.0^{\circ} \mathrm{C}$ ) for 15 min with occasional shaking, then at elevated temperature $\left(\vartheta=25.2{ }^{\circ} \mathrm{C}\right)$ for $15 \mathrm{~min}$, until the stock preparations were nearly dissolved (AMPA full, iodine not fully). Then the AMPA stock solution was injected into the first iodine stock solution (it results solution A), no decoloration resulted. The $\mathrm{H}_{2} \mathrm{O}$ blank was injected into the second iodine stock solution (it results solution $\mathbf{B}$ ), no decoloration resulted. The concentrations in solution were now: AMPA, $102.0653 \mathrm{mM}$; iodine as $\mathrm{I}_{2}, 105.0655 \mathrm{mM}$.

After incubation at elevated temperature for $15 \mathrm{~min}$, into both solutions 1,000 $\mu \mathrm{l}$ of water were injected, crystallization of elemental iodine followed, and no decoloration resulted. The first photograph series (Figure 7) was taken after $25 \mathrm{~min}$ incubation at elevated temperature. After incubation at elevated temperature for $15 \mathrm{~min}, 2,000 \mu \mathrm{l}$ of $90 \%(v / v)$ aqueous ethanol were injected in both $\mathbf{A}$ and $\mathbf{B}$. The mixtures were shaken, the iodine dissolved to give clear deep brown solutions, and no decoloration resulted. After $5 \mathrm{~min}$ incubation at elevated temperature the second photograph (Figure 7) series was taken. Both A and B did not show any further change at RT during $24 \mathrm{~h}$ observation.

\subsection{Color Assay for Cyclo-Os-Na+ Contained in $\mathrm{RC}$ - Destruction of Cyclo-Os- $\mathrm{Na}^{+}$by Glyphosate and ROUNDUP®}

Stock preparations were: $\mathbf{R C}+\mathrm{KI}+$ starch $\left(34 \mathrm{mg} \mathbf{R C}+57 \mathrm{mg} \mathrm{KI}+18 \mathrm{mg}\right.$ starch in 2,000 $\mu \mathrm{l} \mathrm{H}_{2} \mathrm{O}$ ) (1), RC + KI + starch + glyphosate $(34 \mathrm{mg} \mathrm{RC}+57 \mathrm{mg} \mathrm{KI}+18 \mathrm{mg}$ starch $+34 \mathrm{mg}$ glyphosate in 2,000 $\mu \mathrm{l}$ $\left.\mathrm{H}_{2} \mathrm{O}\right)(2), \mathbf{R C}+\mathrm{KI}+$ starch + glyphosate-Na (34 mg RC + $57 \mathrm{mg} \mathrm{KI}+18 \mathrm{mg}$ starch + $87 \mathrm{mg}$ ROUNDUP® GRAN in 2,000 $\mu \mathrm{l} \mathrm{H} \mathrm{H}_{2} \mathrm{O}$ ) (3), RC + KI + glyphosate (34 mg RC + $57 \mathrm{mg} \mathrm{KI}+34 \mathrm{mg}$ glyphosate in 2,000 $\mu \mathrm{l}$ $\mathrm{H}_{2} \mathrm{O}$ ) (4), RC + KI + glyphosate-Na (34 mg RC + $57 \mathrm{mg} \mathrm{KI}+87 \mathrm{mg}$ ROUNDUP® GRAN in 2,000 $\mu \mathrm{l} \mathrm{H} \mathrm{H}_{2} \mathrm{O}$ ) (5) [a saturated solution of $18 \mathrm{mg}$ glyphosate (free acid) in 1,000 $\mu \mathrm{l}$ of $\mathrm{H}_{2} \mathrm{O}$ showed $\mathrm{pH} 1.5\left(14.0^{\circ} \mathrm{C}\right)$ ]. The concentrations in solution were: RC, $16.9481 \mathrm{mM}$ (with cyclo-Os- $\mathrm{Na}^{+}, 67.7924 \mathrm{mM}$ ); KI, $171.6867 \mathrm{mM}$; glyphosate, $100.5501 \mathrm{mM}$; glyphosate-Na, $108.1523 \mathrm{mM}$. The stock solutions were incubated at room temperature (RT, $\vartheta=14.7^{\circ} \mathrm{C}$ ) for $30 \mathrm{~min}$, then at elevated temperature $\left(\vartheta=25.2^{\circ} \mathrm{C}\right)$ for $70 \mathrm{~min}$, after which time the photograph series (Figure 9) was taken. 
A control color assay for potential reduction of elemental iodine by glyphosate and ROUNDUP® GRAN was performed. Stock preparations were: blank without glyphosate [75 mg elemental iodine in $2,000 \mu \mathrm{l} 45 \%(v / v)$ aqueous ethanol], glyphosate stock solution [52 mg glyphosate in 2,000 $\mu \mathrm{l} 45 \%(v / v)$ aqueous ethanol], and ROUNDUP® GRAN stock solution [124 mg ROUNDUP® GRAN in 2,000 $\mu \mathrm{l} 45 \%$ $(v / v)$ aqueous ethanol]. The stock preparations were incubated at room temperature (RT, $\left.\vartheta=14.1^{\circ} \mathrm{C}\right)$ for $45 \mathrm{~min}$ with occasional shaking. Then $75 \mathrm{mg}$ solid elemental iodine were added to both glyphosate and ROUNDUP® GRAN stock preparation. After incubation at elevated temperature for $1.5 \mathrm{~h}$, the stock preparations were nearly dissolved (ROUNDUP® GRAN full, glyphosate and iodine not fully). Then $1,000 \mu \mathrm{l}$ of $90 \%(v / v)$ aqueous ethanol were injected into each preparation [resulting in solution A1 (glyphosate), A2 (glyphosate-Na), and B (blank)], no decoloration resulted. The concentrations in solution were now: glyphosate, $102.5216 \mathrm{mM}$; glyphosate-Na, $102.7654 \mathrm{mM}$; iodine as $\mathrm{I} 2,98.4989 \mathrm{mM}$. The photograph series (Figure 9) was taken after $6 \mathrm{~h}$ incubation at elevated temperature, no decoloration resulted. Both A1, A2, and B did not show any further change at RT during 24 h observation.

A color assay for cyclo-O $8-\mathrm{Na}^{+}$contained in $\mathrm{NC}$ was accordingly performed. The preparation was: $\mathrm{NC}+\mathrm{KI}+\operatorname{starch}\left(25 \mathrm{mg} \mathbf{N C}+43 \mathrm{mg} \mathrm{KI}+18 \mathrm{mg}\right.$ starch in 1,000 $\mu_{\mathrm{l} \mathrm{H}} \mathrm{O}$ ). The concentrations in solution were: NC, $18.2452 \mathrm{mM}$ (with cyclo-O8- $\mathrm{Na}^{+}, 18.2452 \mathrm{mM}$ ); KI, $259.0361 \mathrm{mM}$. The preparation was incubated at elevated temperature for $10 \mathrm{~h}$, after which time the first photograph (Figure 9) series was taken. The preparation was further incubated at room temperature (RT, $\vartheta=13.7^{\circ} \mathrm{C}$ ) for $40 \mathrm{~h}$, after which time the second photograph series (Figure 9) was taken.

\subsection{Enzyme Assay of the Glyphosate Metabolite (Aminomethyl)phosphonic Acid with Human Mitochondrial Aminobutyric Acid Transaminase}

Recombinant human (16p13.2) mitochondrial 4-aminobutyrate aminotransferase (ABAT) (E.C. 2.6.1.19), mature full length protein aa 29-500 with N-terminal His-SUMO-tag and C-terminal Myc-tag, was purchased from MyBioSource, Inc. (San Diego, CA, USA). The sequence (472 aa) is: SQAAAKVDVEFDYDGPLMKTEVPGPRSQELMKQLNIIQNAEAVHFFCNYEESRGNYLVDVDGNRML DLYSQISSVPIGYSHPALLKLIQQPQNASMFVNRPALGILPPENFVEKLRQSLLSVAPKGMSQLITMACGS CSNENALKTIFMWYRSKERGQRGFSQEELETCMINQAPGCPDYSILSFMGAFHGRTMGCLATTHSKAI HKIDIPSFDWPIAPFPRLKYPLEEFVKENQQEEARCLEEVEDLIVKYRKKKKTVAGIIVEPIQSEGGDNHA SDDFFRKLRDIARKHGCAFLVDEVQTGGGCTGKFWAHEHWGLDDPADVMTFSKKMMTGGFFHKEEF RPNAPYRIFNTWLGDPSKNLLLAEVINIIKREDLLNNAAHAGKALLTGLLDLQARYPQFISRVRGRGTF CSFDTPDDSIRNKLILIARNKGVVLGGCGDKSIRFRPTLVFRDHHAHLFLNIFSDILADFK (PLP-binding $\mathrm{K}_{357}$ active site in bold). The 500 aa ABAT precursor protein (NCBI Reference Sequence NP_000654.2) additionally bears the N-terminal peptide 1-28. The mature ABAT (aa 29-500, 53.27 kDa) is responsible for the catabolism of -aminobutyric acid (GABA), an important, mostly inhibitory neurotransmitter in the central nervous system, into succinic semialdehyde. The active enzyme is a homodimer of $53 \mathrm{kDa}$ subunits, each condensed to one pyridoxal 5'-phosphate (PLP). The human ABAT deficiency phenotype includes psychomotor retardation, hypotonia, hyperreflexia, lethargy, refractory seizures, and electroencephalographic (EEG) abnormalities.

To investigate whether AMPA is a substrate for human mitochondrial GABA transaminase, experiments were performed with commercially available recombinant human GABA transaminase according to the procedure of Schor et al. [25] with some modifications. Incubations with 500 nmol AMPA, in an assay volume of $120 \mu \mathrm{l}$ did not show activity of GABA transaminase towards AMPA, while the control assay using $500 \mathrm{nmol}{ }^{15} \mathrm{~N}-\mathrm{GABA}$ as substrate did resulted in the formation of the expected enzyme product. Subsequent inhibition experiments, with co-incubations of fixed amounts (500 nmol) of ${ }^{15} \mathrm{~N}-$ GABA with increasing amounts of AMPA (0-2000 nmol), revealed that AMPA did not act as an inhibitor of the GABA transaminase-catalysed reaction of ${ }^{15} \mathrm{~N}-\mathrm{GABA}$ to succinic semialdehyde. These combined results strongly suggest that AMPA is not a substrate for human GABA transaminase. 


\subsection{Enzyme Assay of the Glyphosate Metabolite (Aminomethyl)phosphonic Acid with Human Wild-Type} Alanine:Glyoxylate Aminotransferase

Recombinant human alanine:glyoxylate aminotransferase was expressed in E. coli and purified as described [91]. The enzyme at $5 \mu \mathrm{M}$ concentration was incubated with $100 \mathrm{mM}$ AMPA at $25^{\circ} \mathrm{C}$ in 100 $\mathrm{mM}$ potassium phosphate buffer $\mathrm{pH}$ 7.4. At various times $(1,2,5,22 \mathrm{~h})$, aliquots were withdrawn and the reaction was stopped by adding trichloroacetic acid $10 \%(v / v)$. The total amount of PLP and pyridoxamine 5 -phosphate (PMP) was determined by HPLC analysis as previously described (Figure 11A) [92].

\section{Conclusions}

We allow us the profound conclusions that sperminium phosphate/cyclo-O $8-\mathrm{Na}^{+}$coverage of nucleic acids is essential for eukaryotic gene regulation, and, in conjunction with selenite, protects and stabilizes gene-rich 'open' chromatin euchromatic DNA [5]. These postulations [5] would account for a long-sought molecular explanation of the essential, but 'mysterious' function of the polyamine spermine in eukaryotes [6]. Spermine is found only in eukaryotes, with some exceptions, and prokaryotes rely mostly on putrescine and spermidine [6,93]. The essentiality of spermine for humans is exemplified by the Snyder-Robinson X-linked mental retardation syndrome [94] caused by missense mutations in the human spermine synthase gene, leading to mental retardation, generalised seizures, absent speech, inability to stand, and other severe defects [94]. One can speculate that at the transition from prokaryotic to eukaryotic life the sperminium phosphate/cyclo- $\mathrm{O}_{8}-\mathrm{Na}^{+}$complex resulted as a consequence from the combined accumulation of atmospheric oxygen and prokaryotic RNA, since the evolution of spermine synthases from prokaryotic spermidine synthase was proposed [93] as co-occurring with the onset of proto-eukaryotic life.

An improved and corrected molecular biological model is proposed for a first epigenetic shell of eukaryotic euchromatin. This model incorporates an epigenetic explanation for the interactions of the essential micronutrient selenium (as selenite) with eukaryotic euchromatin. The sperminium phosphate/cyclooctaoxygen sodium complex was calculated to cover the actively transcribed regions (2.6\%) of bovine lymphocyte interphase genome dsDNA (double occupation). The polyamine (spermine/spermidine ratio 1.17) coverage of HeLa S3 cell metaphase chromatin dsDNA was calculated as $93.4 \%$ (single occupation). In murine cryptal enterocytic mitotic (late anaphase/early telophase) chromatin the obtained in vivo value corresponds to complete genomic coverage (single occupation), and to comprehensive and extensive nuclear RNA coverage, by the spermine tetracation and spermidine trication (spermine/spermidine ratio 0.85 ). Because cyclooctaoxygen seems to be naturally absent in hypoxia-induced highly condensed chromatin [4], we hence propose a model [95] for the cyclooctaoxygen sodium-bridged spermine phosphate (and selenite) epigenetic shell of actively transcribed gene regions in eukaryotic 'open' chromatin DNA (Figure 13). Furthermore, a working model is tabulated in summary for the selective cell cycle-dependent epigenetic occupation of eukaryotic DNA (Table 1).

What may be the overall biological significance, and pathophysiological implication, of this selective epigenetic shell? During transcription of actively transcribed gene regions in eukaryotic 'open' chromatin the double helix must be unwound by DNA helicases [96] and the strands must be separated to enable access to DNA-dependent RNA polymerases I, II [97,98], and III. This creates intermediate DNA single-strand regions which are prone to chemical structure damage by multiple noxious impacts like reactive oxygen species (ROS) [3] and mutagens [99]. The selective cyclooctaoxygen sodium-bridged spermine phosphate (and selenite) epigenetic occupation of these sensitive single-stranded stretches could serve as an intrinsic protection against chemically-induced structural damage. This would be a 
logic explanation for the selective nature of the separate occupation of both DNA strands, consequently retained when strands are separated for transcription of mRNA.

But what is the chemical, obviously evolutionary conserved, genomic necessity for the DNA single-strand protection by cyclooctaoxygen sodium-bridged spermine complexes? Since spontaneous deamination, ROS, chemical mutagens, and UV light do damage both dsDNA and ssDNA regions [100102], albeit ssDNA with higher propensity than dsDNA [100,101], the immediate benefit must be based in another origin. Intriguing seem to be $\mathrm{pH}$ effects, since spermine is a strong base, and the major $\mathrm{pH}$ related damage to DNA is depurination creating apurinic sites at low $\mathrm{pH}$ [103-105], with a four times higher reaction rate for ssDNA than for dsDNA $[103,105]$.

The formation of kinetin ( $\mathrm{N}^{6}$-furfuryl-9H-adenine) from DNA is known [106]. It should be emphasized that kinetin is not contained in native mammalian DNA, contrary to misleading claims $[107,108]$, but is formed only during DNA damage. A mechanism for the kinetin formation in, or from, DNA was proposed $[107,108]$, but it seems not to be conclusive in chemical reason, since furfural does not react with the adenine 6- $\mathrm{NH}_{2}$ group under condensation to a Schiff base [106]. We therefore propose a chemical mechanistic deduced logical scheme [109-112] for the generation of kinetin from DNA by proton catalysis (kinetin-generating "base flip", KGBF) (Figure 14), based on proton-catalysed depurination and subsequent inverted adenine 6- $\mathrm{NH}_{2} \mathrm{~N}$-glycosylation $[109,110]$, in consequence leaving back a DNA single-strand break. It is proposed that the cyclooctaoxygen sodium-bridged spermine phosphate epigenetic shell protects ssDNA from low $\mathrm{pH}$-induced depurination, including, in part, generation of kinetin by KGBF. This is substantiated by the precise calculation of the apparent acid dissociation constant of the human genome DNA (see Methods 4.5.).

We therefore conclude that the sperminium phosphate/cyclooctaoxygen sodium complex serves to protect ssDNA from nucleic acid-mediated intrinsic low intranuclear micro-pH-induced depurination, including KGBF, creating apurinic sites and concomitant DNA single-strand breaks at eukaryotic genome regions engaged in active transcription. The precisely calculated intranuclear micro-pH gain, obtained by sperminium phosphate/cyclooctaoxygen sodium complexation of B-DNA individual strands, is essentially the same as the intranuclear micro-pH gain for condensed B-DNA strand-overarchingly covered by sperminium tetracations.

In conclusion, it is logically obvious that any chemical agent, biochemical precursor (selenium) deficiency, and/or physical circumstance compromising the sperminium phosphate/selenitecyclooctaoxygen sodium complexation will inevitably lead to a severe disturbation of eukaryotic genome integrity, to an increased mutation rate, and to genomic DNA single-strand breaks caused by KGBF. This is, in part, proved by the Snyder-Robinson X-linked mental retardation syndrome [94], characterized by a defect in spermine synthesis, leading to nearly complete loss of the polyamine spermine. We therefore investigated chemical agents selectively destroying the epigenetic shell of eukaryotic euchromatin, found a candidate molecule, and, hence, wish to define it as an 'epigenetic poison'. The total herbicide glyphosate, $\mathrm{N}$-(phosphonomethyl)glycine (ROUNDUP®, Monsanto), and its major environmental metabolite (aminomethyl)phosphonic acid (AMPA) [71] were found, rather unequivocally, to selectively destroy the cyclo-Os-Na+ complex contained in $\mathrm{RC}$ (Figure 7, 8, 9 and 10). Glyphosate and AMPA came into focus because (i) glyphosate represents the top selling total herbicide worldwide [72], (ii) their chemical structure (phosphonate + amine) and properties (strongly hydrophilic and acidic) seemed to enable them to interact with cyclooctaoxygen sodium, (iii) glyphosate and ROUNDUP® are suspected to damage DNA and cause cancer in humans [113], and (iv) AMPA is already widely distributed in global ecosystems like (surface) water [114].

We allow us to conclude on basis of our, rather unequivocal, findings that glyphosate, ROUNDUP ${ }^{\circledR}$ and AMPA are major examples of slow-acting, insidious 'epigenetic poisons', (i) slowly eroding and detoriating human, animal and plant genomic integrity, (ii) rattening human, animal and plant inborne protection of hereditary information against mutation, and (iii) disturbing the processing of 
human, animal and plant genetic information by transcription. It is hence inevitable for us to define glyphosate, ROUNDUP® and AMPA as a significant threat for human, animal and plant genomic stability, especially for future human generations forced to live under the glyphosate-, ROUNDUP®- and AMPA-induced radiomimetic effects.

Acknowledgments: The authors thank T. Westfeld, E.-M. May, D. Wiegel, W. Wübbolt, O. Meier, R. Sachs, A. Karbach, W. Bergmeier, J. Moldenhauer and H.-J. Hühn (Currenta GmbH \& Co. OHG, Leverkusen, Germany) for analytical services. We thank H.J. Jodl for helpful discussions. We are obliged to K. Hecker, K. Meuser and K. Hecker (HEKAtech GmbH, Wegberg, Germany) for expert elemental analyses.

Author Contributions: A.J.K., E.A.S., and B.C. conceived and designed the experiments; A.J.K., E.A.S., and B.C. performed experiments; A.J.K., E.A.S., and B.C. analysed the data and wrote the paper. All the authors reviewed all parts of the manuscript.

Conflicts of Interest: The authors declare no conflict of interest.

\section{References}

1. van Leeuwenhoek, A. Observationes D. Anthonii Lewenhoeck, de natis è semine genitali animalculis. Philos. Trans. R. Soc. Lond. 1677-1678, 12, 1040-1046.

2. Rosenheim, O. The isolation of spermine phosphate from semen and testis. Biochem. J. 1924, 18, $1253-1262$.

3. Cooke, M.S.; Evans, M.D.; Dizdaroglu, M.; Lunec, J. Oxidative DNA damage: mechanisms, mutation, and disease. FASEB J. 2003, 17, 1195-1214.

4. Kirmes, I.; Szczurek, A.; Prakash, K; Charapitsa, I.; Heiser, C.; Musheev, M.; Schock, F.; Fornalczyk, K.; Ma, D.; Birk, U.; Cremer, C.; Reid, G. A transient ischemic environment induces reversible compaction of chromatin. Genome Biol. 2015, 16, 246. doi:10.1186/s13059-015-0802-2.

5. Kesel, A.J.; Day, C.W.; Montero, C.M.; Schinazi, R.F. A new oxygen modification cyclooctaoxygen binds to nucleic acids as sodium crown complex. Biochim. Biophys. Acta 2016, 1860, 785-794.

6. Igarashi, K.; Kashiwagi, K. Polyamines: mysterious modulators of cellular functions. Biochem. Biophys. Res. Commun. 2000, 271, 559-564.

7. Ferguson, L.R.; Karunasinghe, N.; Zhu, S.; Wang, A.H. Selenium and its' role in the maintenance of genomic stability. Mutat. Res. 2012, 733, 100-110.

8. Freiman, Yu.A.; Jodl, H.J. Solid oxygen. Phys. Rep. 2004, 401, 1-288.

9. Lundegaard, L.F.; Weck, G.; McMahon, M.I.; Desgreniers, S.; Loubeyre, P. Observation of an Os molecular lattice in the phase of solid oxygen. Nature 2006, 443, 201-204.

10. Kim, K.S.; Jang, J.H.; Kim, S.; Mhin, B.-J.; Schaefer, H.F., III. Potential new high energy density materials: cyclooctaoxygen $\mathrm{O}_{8}$, including comparisons with the well-known cyclo-Ss molecule. J. Chem. Phys. 1990, 92, 1887-1892.

11. Shapiro, R.; Agarwal, S.C. Reaction of ninhydrin with cytosine derivatives. J. Am. Chem. Soc. 1968, 90, 474-478. 
12. Doherty, E.A.; Doudna, J.A. Ribozyme structures and mechanisms. Annu. Rev. Biophys. Biomol. Struct. 2001, 30, 457-475.

13. Mielcarek, M.; Barciszewska, M.Z.; Sałanski, P.; Stobiecki, M.; Jurczak, J.; Barciszewski, J. Native transfer RNA catalyzes Diels-Alder reaction. Biochem. Biophys. Res. Commun. 2002, 294, 145-148.

14. Ruzin, A.; Severin, A.; Ritacco, F.; Tabei, K.; Singh, G.; Bradford, P.A.; Siegel, M.M.; Projan, S.J.; Shlaes, D.M. Further evidence that a cell wall precursor [C55-MurNAc-(peptide)-GlcNAc] serves as an acceptor in a sorting reaction. J. Bacteriol. 2002, 184, 2141-2147.

15. Watson, J.D.; Crick, F.H.C. Genetical implications of the structure of deoxyribonucleic acid. Nature 1953, 171, 964-967.

16. Herbstein, F.H.; Kapon, M.; Schwotzer, W. Crystal structure of tetrakis(phenacetin) dihydrogentetraiodide dihydrate $\left\{\left[\mathrm{H}_{5} \mathrm{C}_{2} \mathrm{OC}_{6} \mathrm{H}_{4} \mathrm{~N}(\mathrm{H}) \mathrm{C}\left(\mathrm{CH}_{3}\right)=\mathrm{O}_{4} \bullet \mathrm{H}_{2} \mathrm{I}_{4} \bullet 2 \mathrm{H}_{2} \mathrm{O}\right\}\right.$. Helv. Chim. Acta $1983,66,35-43$.

17. Hitchcock, P.B.; Hughes, D.L.; Leigh, G.J.; Sanders, J.R.; de Souza, J.; McGarry, C.J.; Larkworthy, L.F. Preparation of new vanadium(II) iodides and crystal structure of hexakis(acetonitrile)vanadium(II) (tetraiodide). J. Chem. Soc., Dalton Trans. 1994, 3683-3687.

18. Genser, E.E.; Connick, R.E. Exchange of iodide ion with triiodide ion studied by nuclear magnetic resonance. J. Chem. Phys. 1973, 58, 990-996.

19. Schenck, H.-U.; Simak, P.; Haedicke, E. Structure of polyvinylpyrrolidone-iodine (povidoneiodine). J. Pharm. Sci. 1979, 68, 1505-1509.

20. Herbstein, F.H.; Kapon, M. Zigzag chains of alternating iodine molecules and triiodide ions in crystalline (phenacetin) 2 • HIs. Nature Phys. Sci. 1972, 239, 153-154.

21. Saenger, W. The structure of the blue starch-iodine complex. Naturwissenschaften 1984, 71, 31-36.

22. Svensson, P.H.; Kloo, L. Synthesis, structure, and bonding in polyiodide and metal iodide-iodine systems. Chem. Rev. 2003, 103, 1649-1684.

23. Tomlin, C.D.S. (Ed.) The pesticide manual: a world compendium, incorporating the agrochemicals handbook. 11 $1^{\text {th }}$ Edn., British Crop Protection Council (Farnham, Surrey, UK), 1997.

24. Terpstra, K.R.; Woortman, A.J.J.; Hopman, J.C.P. Yellow dextrins: evaluating changes in structure and colour during processing. Starch/Stärke 2010, 62, 449-457.

25. Shor, D.S.M.; Struys, E.A.; Hogema, B.M.; Gibson, K.M.; Jakobs, C. Development of a stable-isotope dilution assay for -aminobutyric acid (GABA) transaminase in isolated leukocytes and evidence that GABA and -alanine transaminases are identical. Clin. Chem. 2001, 47, 525-531.

26. Cellini, B.; Bertoldi, M.; Montioli, R.; Paiardini, A.; Borri Voltattorni, C. Human wild-type alanine:glyoxylate aminotransferase and its naturally occurring G82E variant: functional properties and physiological implications. Biochem. J. 2007, 408, 39-50.

27. Lever, M.A.; Torti, A.; Eickenbusch, P.; Michaud, A.B.; Šantl-Temkiv, T.; Jørgensen, B.B. A modular method for the extraction of DNA and RNA, and the separation of DNA pools from diverse environmental sample types. Front. Microbiol. 2015, 6, 476. doi:10.3389/fmicb.2015.00476.

28. Binns, E.H. The dissociation constant of phenol in water between $25^{\circ} \mathrm{C}$ and $60^{\circ} \mathrm{C}$. Trans. Faraday Soc. 1959, 55, 1900-1903. 
29. Takeda, Y.; Samejima, K.; Nagano, K.; Watanabe, M.; Sugeta, H.; Kyogoku, Y. Determination of protonation sites in thermospermine and in some other polyamines by ${ }^{15} \mathrm{~N}$ and ${ }^{13} \mathrm{C}$ nuclear magnetic resonance spectroscopy. Eur. J. Biochem. 1983, 130, 383-389.

30. Aikens, D.; Bunce, S.; Onasch, F.; Parker, R., III.; Hurwitz, C.; Clemans, S. The interactions between nucleic acids and polyamines. II. Protonation constants and ${ }^{13} \mathrm{C}-\mathrm{NMR}$ chemical shift assignments of spermidine, spermine, and homologs. Biophys. Chem. 1983, 17, 67-74.

31. Fukuzumi, S.; Yorisue, T. Quinone/hydroxide ion induced oxygenation of $p$-benzoquinone to rhodizonate dianion $\left(\mathrm{C}_{6} \mathrm{O}_{6}{ }^{2-}\right)$ accompanied by one-electron reduction to semiquinone radical anion. J. Am. Chem. Soc. 1991, 113, 7764-7765.

32. Vogel, F.; Harf, J.; Hug, A.; von Rohr, P.R. Promoted oxidation of phenol in aqueous solution using molecular oxygen at mild conditions. Environ. Prog. 1999, 18, 7-13.

33. Kay, E.R.M.; Simmons, N.S.; Dounce, A.L. An improved preparation of sodium desoxyribonucleate. J. Am. Chem. Soc. 1952, 74, 1724-1726.

34. Emanuel, C.F.; Chaikoff, I.L. The large scale preparation of sodium desoxyribonucleate from ripe salmon testes. J. Biol. Chem. 1953, 203, 167-171.

35. Waddington, C.H. The epigenotype. Endeavour (Engl. Ed. Lond.) 1942, 1, 18-20.

36. Crick, F.H.C.; Watson, J.D. The complementary structure of deoxyribonucleic acid. Proc. R. Soc. Lond. A Math. Phys. Sci. 1954, 223, 80-96.

37. Schlegel, M.K.; Essen, L.-O.; Meggers, E. Duplex structure of a minimal nucleic acid. J. Am. Chem. Soc. 2008, 130, 8158-8159.

38. Heinemann, U.; Lauble, H.; Frank, R.; Blöcker, H. Crystal structure analysis of an A-DNA fragment at 1.8 Å resolution: d(GCCCGGGC). Nucleic Acids Res. 1987, 15, 9531-9550.

39. Mandal, P.K.; Venkadesh, S.; Gautham, N. Structure of the tetradecanucleotide d(CCCCGGTACCGGGG) 2 as an A-DNA duplex. Acta Crystallogr. Sect. F Struct. Biol. Cryst. Commun. 2012, 68, 393-399.

40. Saenger, W.; Hunter, W.N.; Kennard, O. DNA conformation is determined by economics in the hydration of phosphate groups. Nature 1986, 324, 385-388.

41. Leder, P.; Nirenberg, M. RNA codewords and protein synthesis, II. Nucleotide sequence of a valine RNA codeword. Proc. Natl. Acad. Sci. USA 1964, 52, 420-427.

42. Watanabe, S.; Kusama-Eguchi, K.; Kobayashi, H.; Igarashi, K. Estimation of polyamine binding to macromolecules and ATP in bovine lymphocytes and rat liver. J. Biol. Chem. 1991, 266, 20803-20809.

43. Sunkara, P.S.; Ramakrishna, S.; Nishioka, K.; Rao, P.N. The relationship between levels and rates of synthesis of polyamines during mammalian cell cycle. Life Sci. 1981, 28, 1497-1506.

44. Li, G.; Sudlow, G.; Belmont, A.S. Interphase cell cycle dynamics of a late-replicating, heterochromatic homogeneously staining region: precise choreography of condensation/decondensation and nuclear positioning. J. Cell Biol. 1998, 140, 975-989.

45. Goyns, M.H. Polyamine content of a non-aqueously isolated chromosome preparation. Exp. Cell Res. 1979, 122, 377-380. 
46. Jain, S.; Zon, G.; Sundaralingam, M. Base only binding of spermine in the deep groove of the ADNA octamer d(GTGTACAC). Biochemistry 1989, 28, 2360-2364.

47. Egli, M.; Williams, L.D.; Gao, Q.; Rich, A. Structure of the pure-spermine form of Z-DNA (magnesium free) at 1-Å resolution. Biochemistry 1991, 30, 11388-11402.

48. Ohishi, H.; Nakanishi, I.; Inubushi, K.; van der Marel, G.; van Boom, J.H.; Rich, A.; Wang, A.H.J.; Hakoshima, T.; Tomita, K. Interaction between the left-handed Z-DNA and polyamine-2. The crystal structure of the $\mathrm{d}(\mathrm{CG})_{3}$ and spermidine complex. FEBS Lett. 1996, 391, 153-156.

49. Ohishi, H.; Tozuka, Y.; Da-Yang, Z.; Ishida, T.; Nakatani, K. The rare crystallographic structure of $\mathrm{d}(\mathrm{CGCGCG})$ : the natural spermidine molecule bound to the minor groove of left-handed Z-DNA d(CGCGCG)2 at $10{ }^{\circ}$ C. Biochem. Biophys. Res. Commun. 2007, 358, 24-28.

50. Tari, L.W.; Secco, A.S. Base-pair opening and spermine binding-B-DNA features displayed in the crystal structure of a gal operon fragment: implications for protein-DNA recognition. Nucleic Acids Res. 1995, 23, 2065-2073.

51. Cameron, I.L.; Smith, N.K.R.; Pool, T.B. Element concentration changes in mitotically active and postmitotic enterocytes. An X-ray microanalysis study. J. Cell Biol. 1979, 80, 444-450.

52. Matera, A.G.; Terns, R.M.; Terns, M.P. Non-coding RNAs: lessons from the small nuclear and small nucleolar RNAs. Nat. Rev. Mol. Cell. Biol. 2007, 8, 209-220.

53. Llères, D.; James, J.; Swift, S.; Norman, D.G.; Lamond, A.I. Quantitative analysis of chromatin compaction in living cells using FLIM-FRET. J. Cell Biol. 2009, 187, 481-496.

54. Thomas, T.J.; Gunnia, U.B.; Thomas, T. Polyamine-induced B-DNA to Z-DNA conformational transition of a plasmid DNA with (dG-dC) $n$ insert. J. Biol. Chem. 1991, 266, 6137-6141.

55. Deng, H.; Bloomfield, V.A.; Benevides, J.M.; Thomas, G.J., Jr. Structural basis of polyamine-DNA recognition: spermidine and spermine interactions with genomic B-DNAs of different GC content probed by Raman spectroscopy. Nucleic Acids Res. 2000, 28, 3379-3385.

56. Rich, A.; Zhang, S. Z-DNA: the long road to biological function. Nat. Rev. Genet. 2003, 4, 566-572.

57. Ha, S.C.; Lowenhaupt, K.; Rich, A.; Kim, Y.-G.; Kim, K.K. Crystal structure of a junction between BDNA and Z-DNA reveals two extruded bases. Nature 2005, 437, 1183-1186.

58. Katchalsky, A.; Gillis, J. Theory of the potentiometric titration of polymeric acids. Recl. Trav. Chim. Pays-Bas 1949, 68, 879-897.

59. Kuhn, W.; Kuhn, H. Die Frage nach der Aufrollung von Fadenmolekülen in strömenden Lösungen. Helv. Chim. Acta 1943, 26, 1394-1465.

60. Rhodes, C.T. Determination of micro-pH in solid drug delivery systems. Drug Dev. Ind. Pharm. 1999, 25, 1221-1222.

61. Flohé, L.; Andreesen, J.R.; Brigelius-Flohé, R.; Maiorino, M.; Ursini, F. Selenium, the element of the moon, in life on earth. IUBMB Life 2000, 49, 411-420.

62. Berzelius, J.J. Lettre de M. Berzelius à M. Berthollet sur deux Métaux nouveaux. Ann. Chim. Phys. (Paris) 1817, 7, 199-206.

63. Borah, S.; Kumar, P.P. Ab initio molecular dynamics study of Se(IV) species in aqueous environment. Phys. Chem. Chem. Phys. 2016, 18, 26755-26763. 
64. Nafisi, S.; Montazeri, M.; Manouchehri, F. The effect of Se salts on DNA structure. J. Photochem. Photobiol. B 2012, 113, 36-41.

65. Nafisi, S.; Manouchehri, F.; Montazeri, M. RNA adducts with $\mathrm{Na}_{2} \mathrm{SeO}_{4}$ and $\mathrm{Na}_{2} \mathrm{SeO}_{3}-\mathrm{Stability}$ and structural features. J. Mol. Struct. 2011, 1006, 547-552.

66. $\mathrm{Wu}$, J.; Lyons, G.H.; Graham, R.D.; Fenech, M.F. The effect of selenium, as selenomethionine, on genome stability and cytotoxicity in human lymphocytes measured using the cytokinesis-block micronucleus cytome assay. Mutagenesis 2009, 24, 225-232.

67. Graupner, A.; Instanes, C.; Andersen, J.M.; Brandt-Kjelsen, A.; Dertinger, S.D.; Salbu, B.; Brunborg, G.; Olsen, A.-K. Genotoxic effects of two-generational selenium deficiency in mouse somatic and testicular cells. Mutagenesis 2015, 30, 217-225.

68. Abdo, K.M. National Toxicology Program (NTP). Technical report on toxicity studies of sodium selenate and sodium selenite (CAS Nos. 13410-01-0 and 10102-18-8) administered in drinking water to F344/N rats and B6C3F1 mice (NIH Publication 94-3387). Toxic. Rep. Ser. 1994, 38, 1-127.

69. Cummins, L.M.; Kimura, E.T. Safety evaluation of selenium sulfide antidandruff shampoos. Toxicol. Appl. Pharmacol. 1971, 20, 89-96.

70. Smyth, H.F., Jr.; Carpenter, C.P.; Weil, C.S.; Pozzani, U.C.; Striegel, J.A.; Nycum, J.S. Range-finding toxicity data: List VII. Am. Ind. Hyg. Assoc. J. 1969, 30, 470-476.

71. Rueppel, M.L.; Brightwell, B.B.; Schaefer, J.; Marvel, J.T. Metabolism and degradation of glyphosate in soil and water. J. Agric. Food Chem. 1977, 25, 517-528.

72. Benbrook, C.M. Trends in glyphosate herbicide use in the United States and globally. Environ. Sci. Eur. 2016, 28, 3. doi:10.1186/s12302-016-0070-0.

73. Holmes, R.P.; Assimos, D.G. Glyoxylate synthesis, and its modulation and influence on oxalate synthesis. J. Urol. 1998, 160, 1617-1624.

74. Helgstrand, E.; Eriksson, B.; Johansson, N.G.; Lannerö, B.; Larsson, A.; Misiorny, A.; Norén, J.O.; Sjöberg, B.; Stenberg, K.; Stening, G.; Stridh, S.; Öberg, B.; Alenius, S.; Philipson, L. Trisodium phosphonoformate, a new antiviral compound. Science 1978, 201, 819-821.

75. Sabourin, C.L.K.; Reno, J.M.; Boezi, J.A. Inhibition of eucaryotic DNA polymerases by phosphonoacetate and phosphonoformate. Arch. Biochem. Biophys. 1978, 187, 96-101.

76. Khan, S.; Ahmed, S. Role of swi7H4 mutant allele of DNA polymerase in the DNA damage checkpoint response. PLoS One 2015, 10, e0124063. doi:10.1371/journal.pone.0124063.

77. Kuse, R.; Schuster, S.; Schübbe, H.; Dix, S.; Hausmann, K. Blood lymphocyte volumes and diameters in patients with chronic lymphocytic leukemia and normal controls. Blut (Berl.) 1985, 50, $243-248$.

78. Sipe, C.R.; Chanana, A.D.; Cronkite, E.P.; Gulliani, G.L.; Joel, D.D. Studies on lymphocytes XIII. Nuclear volume measurement as a rapid approach to estimate proliferative fraction. Scand. J. Haematol. 1976, 16, 196-201.

79. National Center for Biotechnology Information (NCBI). Bos_taurus_UMD_3.1.1, https://www.ncbi.nlm.nih.gov/assembly/GCF 000003055.6/. Bethesda, MD, 2016. 
80. National Center for Biotechnology Information (NCBI). GRCh38.p9, https://www.ncbi.nlm.nih.gov/assembly/GCF 000001405.35/. Bethesda, MD, 2016.

81. Adey, A.; Burton, J.N.; Kitzman, J.O.; Hiatt, J.B.; Lewis, A.P.; Martin, B.K.; Qiu, R.; Lee, C.; Shendure, J. The haplotype-resolved genome and epigenome of the aneuploid HeLa cancer cell line. Nature 2013, 500, 207-211.

82. Macville, M.; Schröck, E.; Padilla-Nash, H.; Keck, C.; Ghadimi, B.M.; Zimonjic, D.; Popescu, N.; Ried, T. Comprehensive and definitive molecular cytogenetic characterization of HeLa cells by spectral karyotyping. Cancer Res. 1999, 59, 141-150.

83. National Center for Biotechnology Information (NCBI). C3H_HeJ_v1, https://www.ncbi.nlm.nih.gov/assembly/738461. Bethesda, MD, 2016.

84. Sarhan, S.; Seiler, N. On the subcellular localization of the polyamines. Biol. Chem. Hoppe-Seyler 1989, 370, 1279-1284.

85. Viola-Magni, M.P.; Gahan, P.B.; Pacy, J. Phospholipids in plant and animal chromatin. Cell Biochem. Funct. 1985, 3, 71-78.

86. Kumler, W.D.; Eiler, J.J. The acid strength of mono and diesters of phosphoric acid. The $n$-alkyl esters from methyl to butyl, the esters of biological importance, and the natural guanidine phosphoric acids. J. Am. Chem. Soc. 1943, 65, 2355-2361.

87. Mandelkern, M.; Elias, J.G.; Eden, D.; Crothers, D.M. The dimensions of DNA in solution. J. Mol. Biol. 1981, 152, 153-161.

88. Langridge, R.; Marvin, D.A.; Seeds, W.E.; Wilson, H.R.; Hooper, C.W.; Wilkins, M.H.F.; Hamilton, L.D. The molecular configuration of deoxyribonucleic acid. II. Molecular models and their Fourier transforms. J. Mol. Biol. 1960, 2, 38-64.

89. Mermer, A.; Starynowicz, P. Charge-density distribution in potassium dihydrogen phosphoglycolate - a comparison of phosphate and phosphonate groups. Acta Crystallogr. B 2012, $68,625-635$.

90. Wiberg, N. (Ed.) Holleman-Wiberg, Lehrbuch der Anorganischen Chemie, 101. Edn., Walter de Gruyter (Berlin, New York), 1995, p. 771.

91. Cellini, B.; Montioli, R.; Bianconi, S.; López-Alonso, J.P.; Borri Voltattorni, C. Construction, purification and characterization of untagged human liver alanine-glyoxylate aminotransferase expressed in Escherichia coli. Protein Pept. Lett. 2008, 15, 153-159.

92. Oppici, E.; Fodor, K.; Paiardini, A.; Williams, C.; Borri Voltattorni, C.; Wilmanns, M.; Cellini, B. Crystal structure of the S187F variant of human liver alanine: glyoxylate aminotransferase associated with primary hyperoxaluria type I and its functional implications. Proteins 2013, 81, 1457-1465; Erratum published: Proteins 2013, 82, 171.

93. Minguet, E.G.; Vera-Sirera, F.; Marina, A.; Carbonell, J.; Blázquez, M.A. Evolutionary diversification in polyamine biosynthesis. Mol. Biol. Evol. 2008, 25, 2119-2128.

94. de Alencastro, G.; McCloskey, D.E.; Kliemann, S.E.; Maranduba, C.M.C.; Pegg, A.E.; Wang, X.; Bertola, D.R.; Schwartz, C.E.; Passos-Bueno, M.R.; Sertié, A.L. New SMS mutation leads to a striking reduction in spermine synthase protein function and a severe form of Snyder-Robinson Xlinked recessive mental retardation syndrome. J. Med. Genet. 2008, 45, 539-543. 
95. Rosa, S.; Shaw, P. Insights into chromatin structure and dynamics in plants. Biology 2013, 2, 1378-1410. doi:10.3390/biology2041378.

96. van Brabant, A.J.; Stan, R.; Ellis, N.A. DNA helicases, genomic instability, and human genetic disease. Annu. Rev. Genomics Hum. Genet. 2000, 1, 409-459.

97. Cramer, P.; Bushnell, D.A.; Kornberg, R.D. Structural basis of transcription: RNA polymerase II at 2.8 Ångstrom resolution. Science 2001, 292, 1863-1876.

98. Bernecky, C.; Herzog, F.; Baumeister, W.; Plitzko, J.M.; Cramer, P. Structure of transcribing mammalian RNA polymerase II. Nature 2016, 529, 551-554.

99. Ames, B.N. Identifying environmental chemicals causing mutations and cancer. Science 1979, 204, $587-593$.

100. Chan, K.; Sterling, J.F.; Roberts, S.A.; Bhagwat, A.S.; Resnick, M.A.; Gordenin, D.A. Base damage within single-strand DNA underlies in vivo hypermutability induced by a ubiquitous environmental agent. PLoS Genet. 2012, 8, e1003149. doi:10.1371/journal.pgen.1003149.

101. Vodička, P.; Hemminki, K. Identification of alkylation products of styrene oxide in single- and double-stranded DNA. Carcinogenesis 1988, 9, 1657-1660.

102. Gordon, L.K.; Haseltine, W.A. Quantitation of cyclobutane pyrimidine dimer formation in doubleand single-stranded DNA fragments of defined sequence. Radiat. Res. 1982, 89, 99-112.

103. Lindahl, T. Instability and decay of the primary structure of DNA. Nature 1993, 362, 709-715.

104. Lindahl, T.; Nyberg, B. Rate of depurination of native deoxyribonucleic acid. Biochemistry 1972, 11, 3610-3618.

105. Loeb, L.A.; Preston, B.D. Mutagenesis by apurinic/apyrimidinic sites. Ann. Rev. Genet. 1986, 20, 201-230.

106. Miller, C.O.; Skoog, F.; Okumura, F.S.; von Saltza, M.H.; Strong, F.M. Isolation, structure and synthesis of kinetin, a substance promoting cell division. J. Am. Chem. Soc. 1956, 78, 1375-1380.

107. Barciszewski, J.; Siboska, G.E.; Pedersen, B.O.; Clark, B.F.C.; Rattan, S.I.S. A mechanism for the in vivo formation of $\mathrm{N}^{6}$-furfuryladenine, kinetin, as a secondary oxidative damage product of DNA. FEBS Lett. 1997, 414, 457-460.

108. Barciszewski, J.; Massino, F.; Clark, B.F.C. Kinetin-a multiactive molecule. Int. J. Biol. Macromol. 2007, 40, 182-192.

109. Fuller, W.D.; Sanchez, R.A.; Orgel, L.E. Studies in prebiotic synthesis. VI. Synthesis of purine nucleosides. J. Mol. Biol. 1972, 67, 25-33.

110. Maurel, M.-C.; Convert, O. Chemical structure of a prebiotic analog of adenosine. Orig. Life Evol. Biosph. 1990, 20, 43-48.

111. Mustard, T.J.L.; Mack, D.J.; Njardarson, J.T.; Cheong, P.H.-Y. Mechanism and the origins of stereospecificity in copper-catalyzed ring expansion of vinyl oxiranes: a traceless dual transitionmetal-mediated process. J. Am. Chem. Soc. 2013, 135, 1471-1475.

112. Ilardi, E.A.; Njardarson, J.T. Ring expansions of vinyloxiranes, -thiiranes, and -aziridines: synthetic approaches, challenges, and catalytic success stories. J. Org. Chem. 2013, 78, 9533-9540. 
113. Koller, V.J.; Fürhacker, V.; Nersesyan, A.; Mišík, M.; Eisenbauer, M.; Knasmueller, S. Cytotoxic and DNA-damaging properties of glyphosate and Roundup in human-derived buccal epithelial cells. Arch. Toxicol. 2012, 86, 805-813.

114. Coupe, R.H.; Kalkhoff, S.J.; Capel, P.D.; Gregoire, C. Fate and transport of glyphosate and aminomethylphosphonic acid in surface waters of agricultural basins. Pest Manag. Sci. 2012, 68, 16-30. doi:10.1002/ps.2212.

(C) 2017 by the authors; licensee Preprints, Basel, Switzerland. This article is an open access article distributed under the terms and conditions of the Creative Commons by Attribution (CC-BY) license (http://creativecommons.org/licenses/by/4.0/). 
Table 1. Tabulation of the selective cell cycle-dependent occupation of eukaryotic DNA by epigenetic

\begin{tabular}{|c|c|c|c|c|c|}
\hline \multicolumn{2}{|c|}{ Cell cycle phase } & \multicolumn{2}{|c|}{ Heterochromatin } & \multicolumn{2}{|c|}{ Euchromatin } \\
\hline Interphase & Function (concise) & $\begin{array}{l}\text { Spermine- } \\
\text { occupation? }\end{array}$ & $\begin{array}{c}\text { Cyclo-Os- } \\
\mathrm{Na}^{+-} \\
\text {occupation? }\end{array}$ & $\begin{array}{l}\text { Spermine- } \\
\text { occupation? }\end{array}$ & $\begin{array}{c}\text { Cyclo-Os- } \\
\mathrm{Na}^{+-} \\
\text {occupation? }\end{array}$ \\
\hline $\mathrm{G}_{0}(\mathrm{Gap} 0)$ & $\begin{array}{l}\text { Resting and } \\
\text { quiescence }\end{array}$ & No & No & $\begin{array}{c}\text { Yes }(2 \times)-\text { With } \\
\text { cyclo-O8-Na+ }\end{array}$ & $\begin{array}{l}\text { Yes }(2 \times)- \\
\text { On 'open' } \\
\text { Chr }\end{array}$ \\
\hline $\mathrm{G}_{1}(\mathrm{Gap} 1)$ & $\begin{array}{l}\text { Transcription and } \\
\text { histone synthesis }\end{array}$ & No & No & $\begin{array}{c}\text { Yes }(2 \times)-\text { With } \\
\text { cyclo-O8- } \mathrm{Na}^{+}\end{array}$ & $\begin{array}{l}\text { Yes }(2 \times)- \\
\text { On 'open' } \\
\text { Chr }\end{array}$ \\
\hline S (Synthesis) & DNA synthesis & No & No & $\begin{array}{c}\text { Yes }(2 \times)-\text { With } \\
\text { cyclo-Os-Na }\end{array}$ & $\begin{array}{l}\text { Yes }(2 \times)- \\
\text { On 'open' } \\
\text { Chr }\end{array}$ \\
\hline $\mathrm{G}_{2}(\mathrm{Gap} 2)$ & Translation & No & No & $\begin{array}{c}\text { Yes }(2 \times)-\text { With } \\
\text { cyclo-Os- } \mathrm{Na}^{+}\end{array}$ & $\begin{array}{l}\text { Yes }(2 \times)- \\
\text { On 'open' } \\
\text { Chr }\end{array}$ \\
\hline Mitosis & Function (concise) & $\begin{array}{l}\text { Spermine- } \\
\text { occupation? }\end{array}$ & $\begin{array}{c}\text { Cyclo-O }{ }_{8-} \\
\mathrm{Na}^{+-} \\
\text {occupation? }\end{array}$ & $\begin{array}{l}\text { Spermine- } \\
\text { occupation? }\end{array}$ & $\begin{array}{c}\text { Cyclo-O8- } \\
\mathrm{Na}^{+-} \\
\text {occupation? }\end{array}$ \\
\hline Prophase & $\begin{array}{l}\text { Chr condenses into } \\
\text { chromosomes, } \\
\text { nucleolus disappears }\end{array}$ & $\begin{array}{c}\text { Yes }(1 \times)- \\
\text { Condensing } \\
\text { Chr }\end{array}$ & No & $\begin{array}{c}\text { Yes }(1 \times)- \\
\text { Condensing } \\
\text { Chr } \\
\end{array}$ & No \\
\hline Prometaphase & $\begin{array}{l}\text { Kinetochore and } \\
\text { polar microtubules } \\
\text { attach, mitotic } \\
\text { spindle formed, } \\
\text { nucleus disappears }\end{array}$ & $\begin{array}{c}\text { Yes }(1 \times)- \\
\text { Condensed Chr }\end{array}$ & No & $\begin{array}{c}\text { Yes }(1 \times)- \\
\text { Condensed Chr }\end{array}$ & No \\
\hline Metaphase & $\begin{array}{l}\text { Centrosomes pull } \\
\text { chromosomes, } \\
\text { chromosome } \\
\text { centromeres line up } \\
\text { at metaphase plate }\end{array}$ & $\begin{array}{c}\text { Yes }(1 \times)- \\
\text { Highly } \\
\text { condensed Chr }\end{array}$ & No & $\begin{array}{c}\text { Yes }(1 \times)- \\
\text { Highly } \\
\text { condensed Chr }\end{array}$ & No \\
\hline Anaphase & $\begin{array}{l}\text { Chromosomes break } \\
\text { at centromeres, sister } \\
\text { chromatids separated } \\
\text { by microtubules }\end{array}$ & $\begin{array}{c}\text { Yes }(1 \times)- \\
\text { Maximally } \\
\text { condensed Chr } \\
\text { in late } \\
\text { anaphase }\end{array}$ & No & $\begin{array}{c}\text { Yes }(1 \times)- \\
\text { Maximally } \\
\text { condensed Chr } \\
\text { in late } \\
\text { anaphase }\end{array}$ & No \\
\hline Telophase & $\begin{array}{l}\text { Chr reformed from } \\
\text { chromosomes, } \\
\text { nucleus and } \\
\text { nucleolus reappear }\end{array}$ & $\begin{array}{c}\text { Yes }(1 \times)- \\
\text { Maximally } \\
\text { condensed Chr } \\
\text { in early } \\
\text { telophase }\end{array}$ & No & $\begin{array}{c}\text { Yes }(1 \times)- \\
\text { Maximally } \\
\text { condensed Chr } \\
\text { in early } \\
\text { telophase }\end{array}$ & No \\
\hline
\end{tabular}

polyamine shells. $1 \times$, single quartet occupation (one polyamine pro both strands); $2 \times$, double triplet occupation (one polyamine pro one strand); Chr, chromatin. 


\section{A Obfervationes D. Anthonii Lewenhoeck, de Natis è Semine genitali Animalculis.}

\section{Nec non AuCtoris barun Tranfactionum Refponfa.}

\section{Obrervatoris Epiftola Honorstif.D.D. Vicecomiti Brsensker, Larinè conferipla; Dat. Nov, J677. Q:ans ipfimiznis tuc tran?suifnsiffis verbis inferendam Auctor cenfuic.}

Nobilifume Vir,

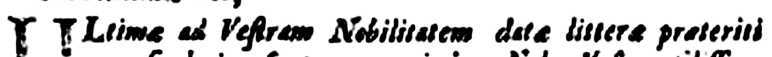

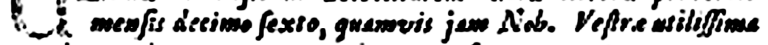
negotic non inserrumpere, animo propofueram, anteguem certo fesrems
B Semel mibi imaginabar me videre figuram quandam, ad magnitudinem arene. quam interne cuidam corporis noftri parti comparare poteram. (urn materia becper momenta quedam aïri fuil]et expofiea, predict a vafum multitudo in aquofam. magnis oleaginofis globulis permiftam, materiam mut abatur: quales globulos inter medulle fpinalis vafa interjacere antehac dixi. Hifce oleaginofis globulis vifis mibi imaginabar, quod for fan fuerint vafa convehendis fpiritibus animalibus injervientia : eaque ex tampmolli conffifere materia, ut, intermittente bumoris vel fpirituum animalium transfluxu, illicù inglobulos oleaginofos diverfa magnitu* dinis coalefcant; precipuè sum ä̈ri exponuntur. Et sumpradict a materia paucillum temporis fteterat, in ea obfervabantur trilaterales fgure ab utraque parte in aculeum defonentes, quibuf. dam longitudo minutifsime arene, aliqua aliquantulum majores,

A A

Figure 1. Parts of the original publication [1] from 1677 by Antoni van Leeuwenhoek with the description of the first light microscopic observation of crystalline spermine phosphate in human semen. (A) The title page 1040. (B) Page 1042 with fig. A showing the characteristic crystalline shape [2] of spermine $\times 2 \mathrm{H}_{3} \mathrm{PO}_{4}$ $\times 6 \mathrm{H}_{2} \mathrm{O}$ [2]. The last paragraph including fig. A is read in New Latin: "Et sum prædicta materia paucillum temporis steterat, in ea observabantur trilaterales figuræ ab utraque parte in aculeum desinentes, quibusdam longitudo minutissimæ arenæ, aliquæ aliquantulum majores, ut fig. A. Prætera, adeo nitidæ ac pellucidæ, ac si crystallinx fuissent.". English transcription: "And I mentioned the matter which stood for a short time, in which trilateral figures were observed from both sides ending in a sting, some in length of minute grains, some a little larger, as fig. A. Moreover, so sleek and translucent, as if it were crystalline.".

A
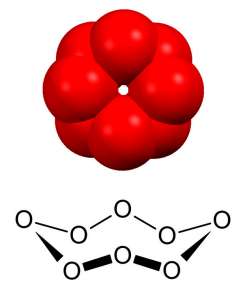<smiles>o1oooooooo1</smiles>

B
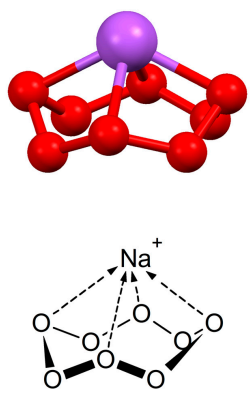

Figure 2. Molecular modeling of cyclooctaoxygen (cyclo-Os) and its $\mathrm{Na}^{+}$complex [5], performed with $\mathrm{ACD} /$ Chem Sketch version 12.01 with integrated ACD/3D Viewer (Advanced Chemistry Development, Inc., Toronto, Ontario, Canada) and processed with Mercury 3.1 version 3.1.1 [The Cambridge Crystallographic Data Centre (CCDC), Cambridge, United Kingdom]. (A) The cyclo-Os octagon (top, space-fill model; middle, crown conformation in $D_{4 d}$ symmetry; bottom, octagon). (B) Molecular modeling of the square pyramidal ( $S P Y-4)$-cyclo- $\mathrm{O}_{8}-\mathrm{Na}^{+}$crown complex. 
A
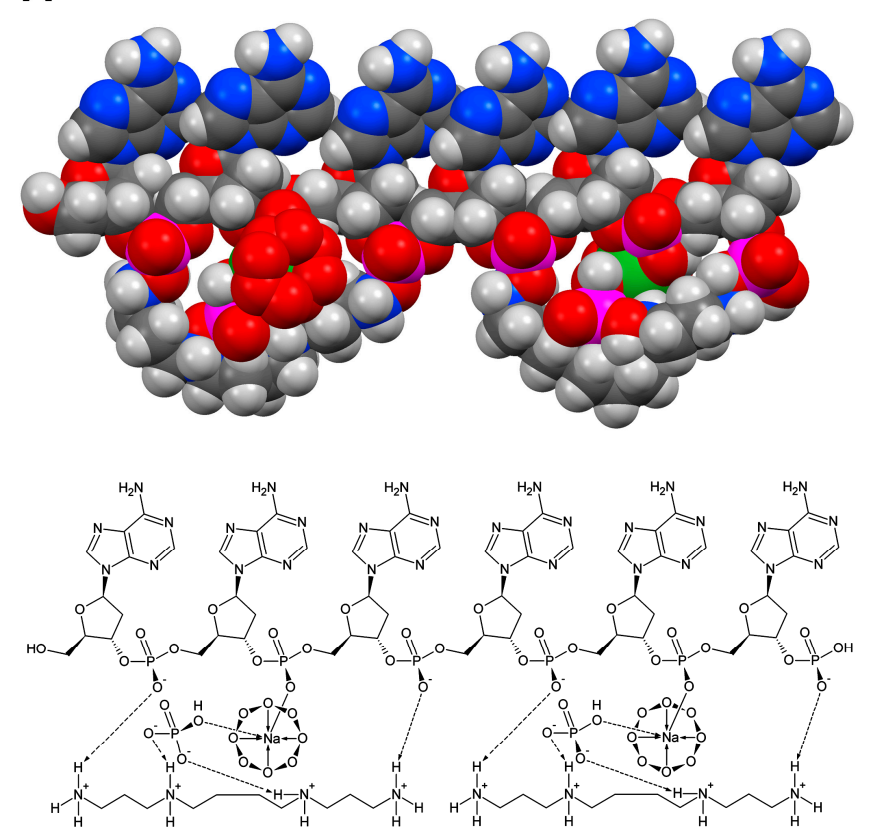

B
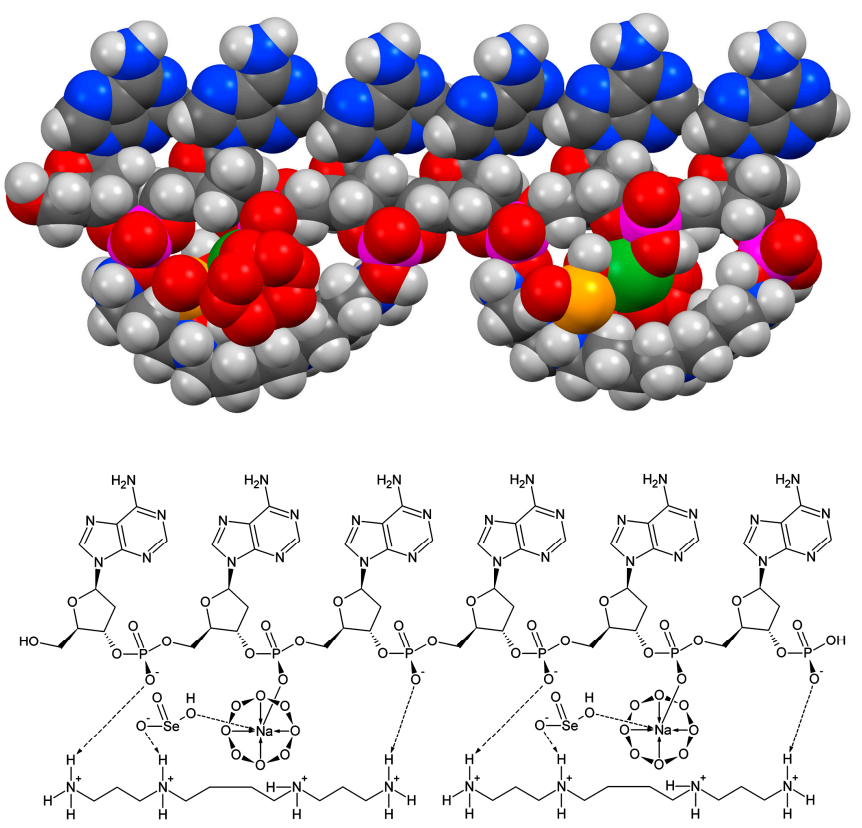

Figure 3. Molecular modeling $[\mathrm{ACD} / \mathrm{Chem}$ Sketch version 12.01 with integrated $\mathrm{ACD} / 3 \mathrm{D}$ Viewer (Advanced Chemistry Development, Inc., Toronto, Ontario, Canada), Mercury 3.1 version 3.1.1 (The Cambridge Crystallographic Data Centre, Cambridge, United Kingdom)] of the postulated [5] first epigenetic shell of euchromatic in vivo DNA, as exemplified for a single-stranded hexanucleotide, introducing a molecular biological model for sperminium phosphate/cyclo-O $8-\mathrm{Na}^{+} / \mathrm{ssDNA}$ and sperminium selenite/cyclo- $\mathrm{O}_{8}-\mathrm{Na}^{+} / \mathrm{ssDNA}$ interactions. (A) The molecular model of the single-stranded hexanucleotide $\mathrm{d}\left(\mathrm{ApApApApApAp)}\right.$ liganded with cyclo-Os- $\mathrm{Na}^{+}$and sperminium phosphate. (B) The molecular model of $\mathrm{d}\left(\mathrm{ApApApApApAp)}\right.$ liganded with cyclo-Os- $\mathrm{Na}^{+}$and sperminium selenite. Element color codings for (A) and (B): gray, carbon; white, hydrogen; blue, nitrogen; red, oxygen; purple, phosphorus; green, sodium; yellow, selenium. 


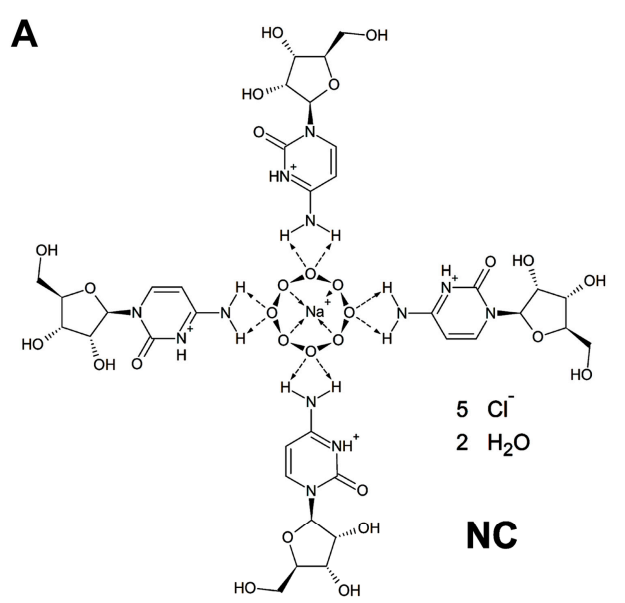

B

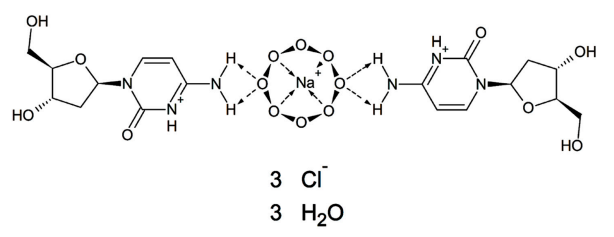

dNC
C

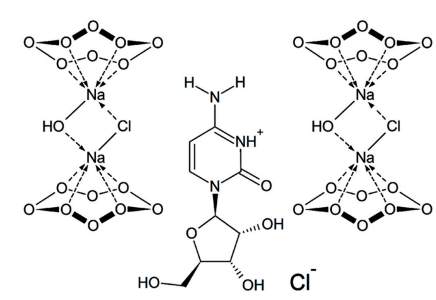

RC

Figure 4. The chemical structures of cyclo-O $8-\mathrm{Na}^{+}$-containing complexes [5]. (A) The cyclo-Os-Na+containing complex NC synthesized by refluxing cytidine $\times \mathrm{HCl}$ with ninhydrin under influence of atmospheric $\mathrm{O}_{2}$. (B) The cyclo-Os- $\mathrm{Na}^{+}$-containing complex dNC synthesized by refluxing 2'-deoxycytidine $\times \mathrm{HCl}$ with ninhydrin under influence of atmospheric $\mathrm{O}_{2}$. (C) The cyclo-Os- $\mathrm{Na}^{+}$-containing complex RC synthesized by biomimetic reaction with buffered $3 \% \mathrm{H}_{2} \mathrm{O}_{2}$ as catalysed (catalase effect) by Candida utilis low-molecular weight $\mathrm{RNA}$ and $\mathrm{NaHCO}_{3}$ at ambient temperature and physiological $\mathrm{pH}$. 


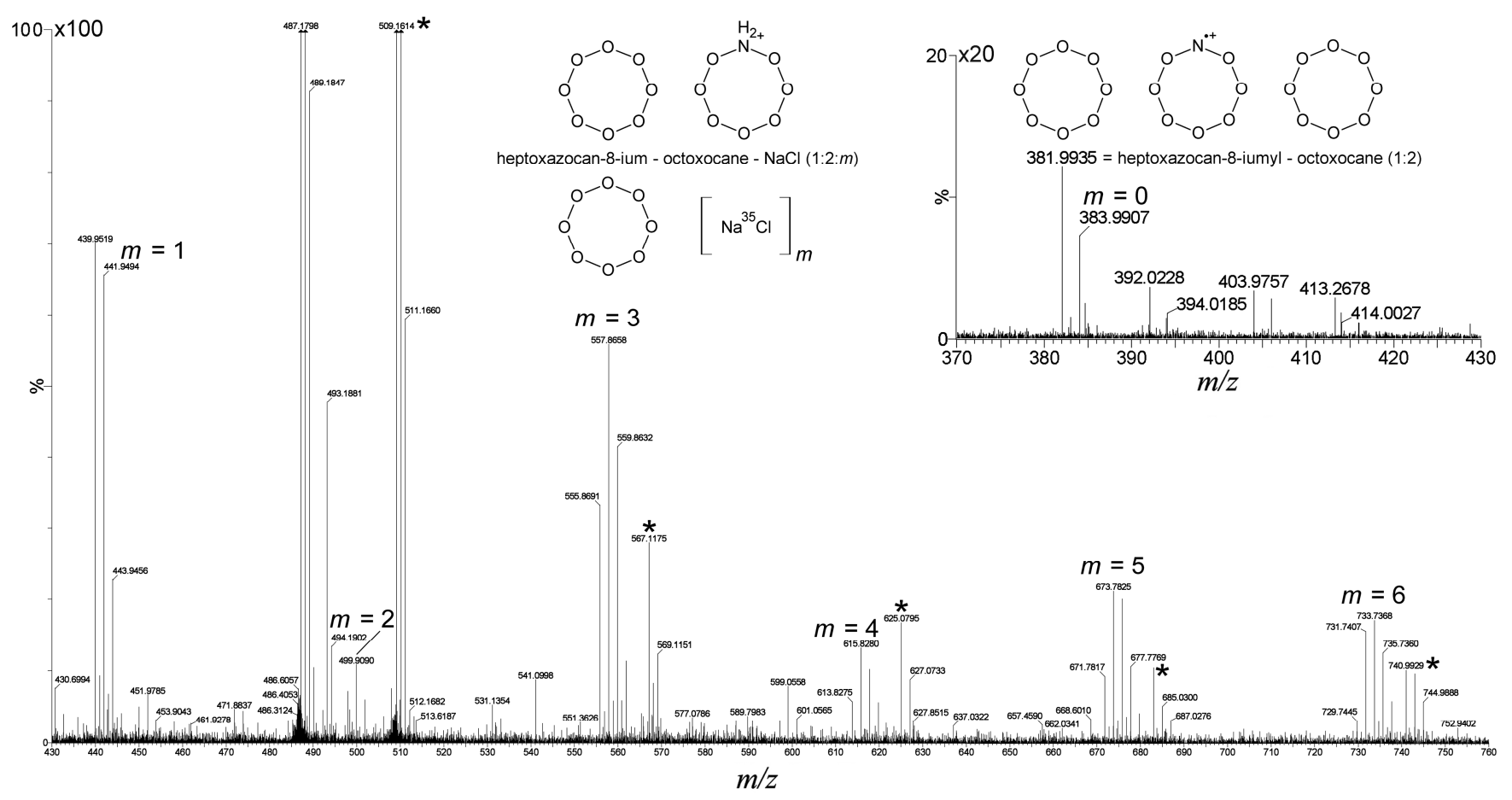

Figure 5. Electrospray ionization mass spectrometry of RC [5]. Magnified $(100 \times)$ section of the ESI-MS spectrum of $\mathbf{R C}$ dissolved in $\mathrm{H}_{2} \mathrm{O} /$ methanol from $\mathrm{m} / \mathrm{z} 430$ to $\mathrm{m} / \mathrm{z} 760$. Inset, magnified $(20 \times)$ segment of the ESI-MS spectrum of RC from $\mathrm{m} / \mathrm{z} 370$ to $\mathrm{m} / \mathrm{z} 430$. The cluster cations of heptoxazocan-8-ium octoxocane $-\mathrm{Na}^{35} \mathrm{Cl}(1: 2: m)$ are marked $(m=0-6)$. Not marked are the +2 isotope peaks resulting from ${ }^{37} \mathrm{Cl}$ instead of one ${ }^{35} \mathrm{Cl}(m=1-6)$. The origin of the heptoxazocan-8-iumyl - octoxocane (1:2) cluster radical cations $\left(-2\right.$ peaks) is indicated in the inset. The cluster cations of $\left[(\text { cytidine })_{2}+\mathrm{Na}+(\mathrm{NaCl})_{n}\right]^{+}(n=0-5)$ are marked with stars. 


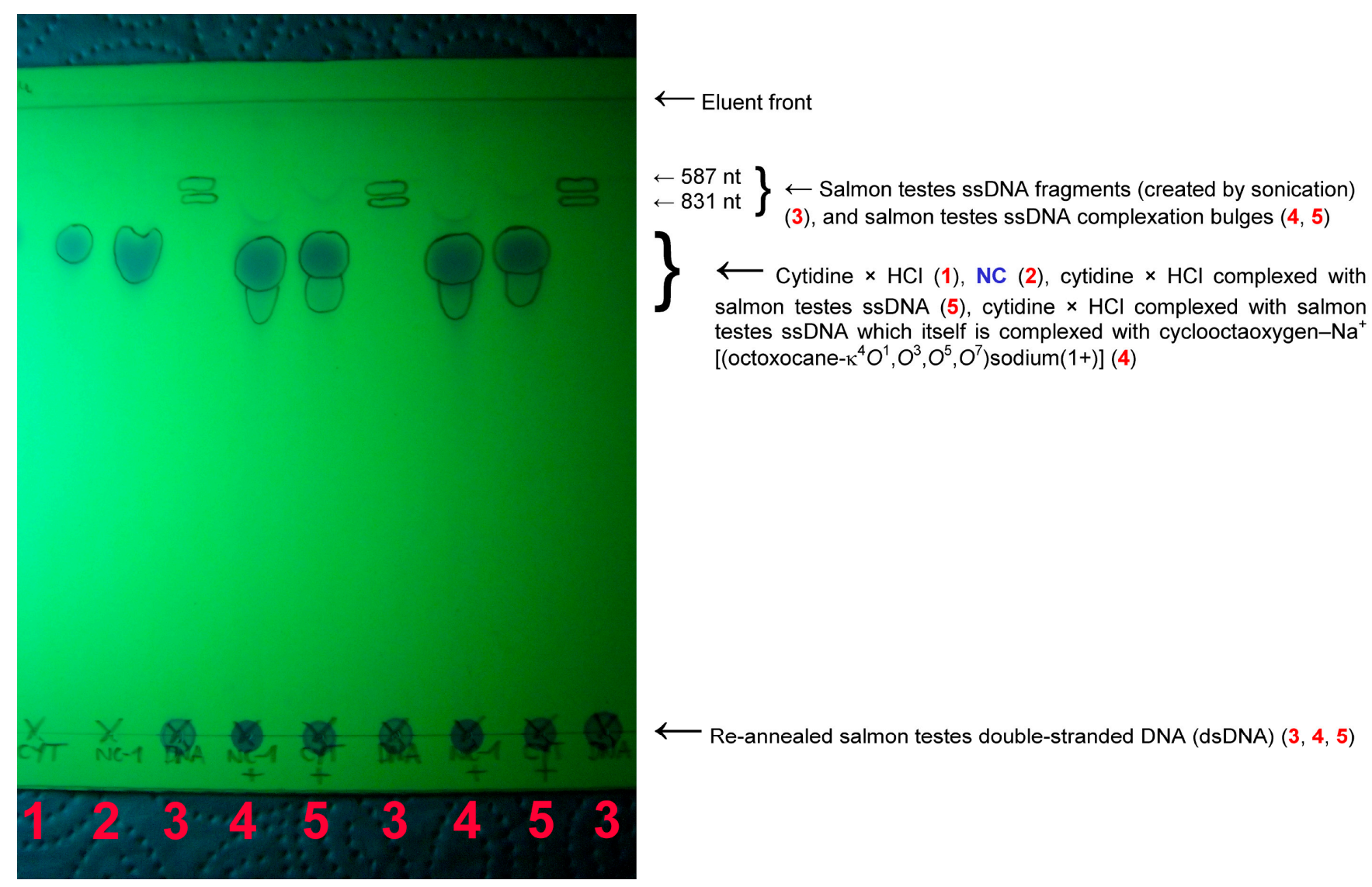

Figure 6. Thin-layer chromatographic mobility shift assay of the binding of NC to salmon testes ssDNA fragments (sonicated salmon testes genomic DNA) [5]. (1) Cytidine $\times \mathrm{HCl}$, incubation at RT for $1 \mathrm{~h} 15$ min, $40 \mu \mathrm{l}$ solution on spot. (2) NC, incubation at RT for $1 \mathrm{~h} 15 \mathrm{~min}, 40 \mu \mathrm{l}$ solution on spot. (3) Salmon testes ssDNA, $100 \mu \mathrm{l}$ salmon testes ssDNA colloidal stock solution diluted with $300 \mu \mathrm{l} \mathrm{H}_{2} \mathrm{O}$, incubation at RT for $55 \mathrm{~min}, 80 \mu \mathrm{l}$ colloidal solution on spot. (4) Salmon testes ssDNA + NC, $700 \mu \mathrm{l}$ salmon testes ssDNA colloidal stock solution added to $500 \mu \mathrm{l}$ of NC stock solution, incubation at RT for $1 \mathrm{~h}, 80 \mu \mathrm{l}$ colloidal solution on spot. (5) Salmon testes ssDNA + cytidine $\times \mathrm{HCl}, 200 \mu \mathrm{l}$ salmon testes ssDNA colloidal stock solution added to $500 \mu \mathrm{l}$ of cytidine $\times \mathrm{HCl}$ stock solution, incubation at RT for $1 \mathrm{~h}, 80 \mu \mathrm{l}$ colloidal solution on spot. 


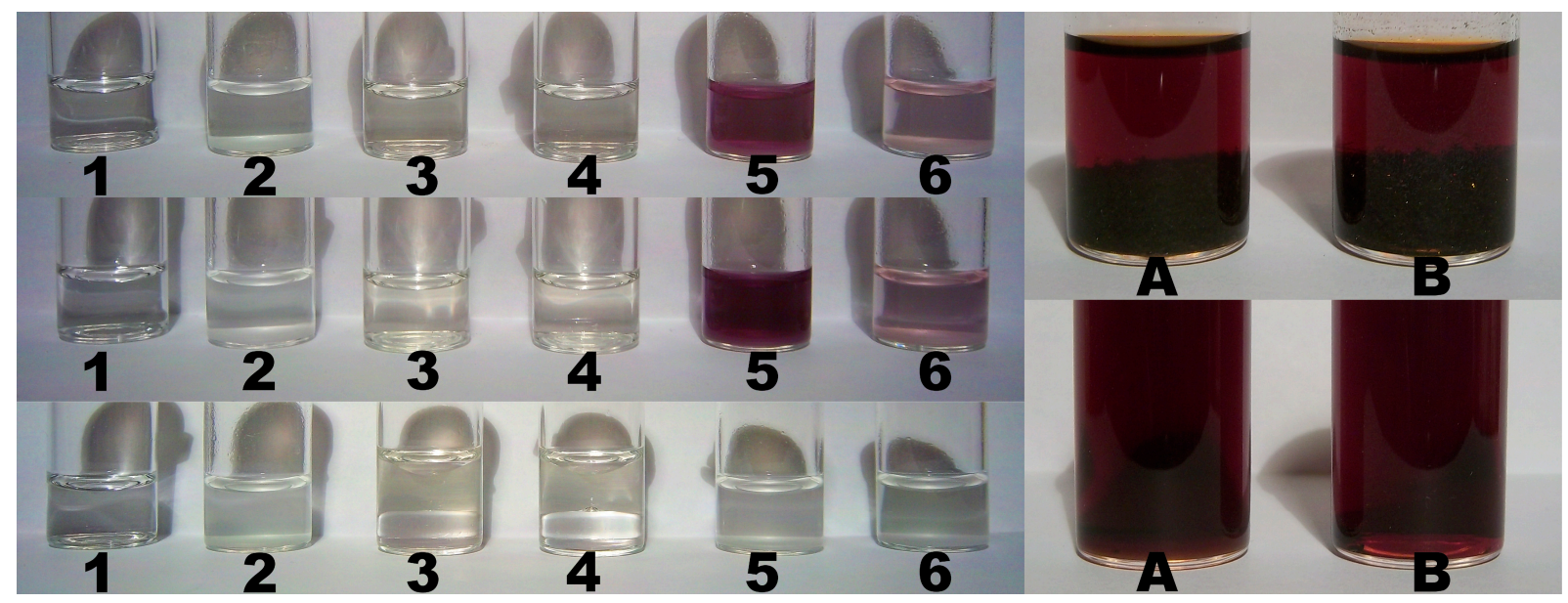

Figure 7. Color assays for cyclo- $\mathrm{O}_{8}-\mathrm{Na}^{+}$contained in $\mathbf{R C}$, for the destruction of cyclo- $\mathrm{O}_{8}-\mathrm{Na}^{+}$by the glyphosate metabolite (aminomethyl)phosphonic acid (AMPA) (left, 1-6), and for the potential reduction of elemental iodine by AMPA (right, A and B). Solutions (left, 1-6) were: KI (1), KI + starch (2), RC + KI (3), RC + KI + AMPA (4), RC + KI + starch (5), and RC + KI + starch + AMPA (6). The concentrations in solution were: RC, $16.95 \mathrm{mM}$ (with cyclo-Os-Na+, $67.79 \mathrm{mM}$ ); KI, 156.63 mM; AMPA, 99.06 mM. The solutions were incubated at two room temperatures for prolonged time. Afterwards (left, bottom row), both RC + KI (3) and RC + KI + AMPA (4) were extracted with deuterated chloroform (bottom phase), and (left, bottom row ) both RC + KI + starch (5) and RC + KI + starch + AMPA (6) were treated with Lascorbic acid. Legend: left, top row (1-6) = first photograph series; left, middle row $(\mathbf{1}-\mathbf{6})=$ second photograph series; left, bottom row (1-6) = third photograph series; right, top row (first photograph series): (A) AMPA (76.55 mM) + iodine (as $\left.\mathrm{I}_{2}, 78.80 \mathrm{mM}\right),(\mathbf{B})$ iodine (as $\left.\mathrm{I}_{2}, 78.80 \mathrm{mM}\right)$; right, bottom row (second photograph series): (A) AMPA (51.03 mM) + iodine (as I2, $52.53 \mathrm{mM})$, (B) iodine (as I2, $52.53 \mathrm{mM})$. 


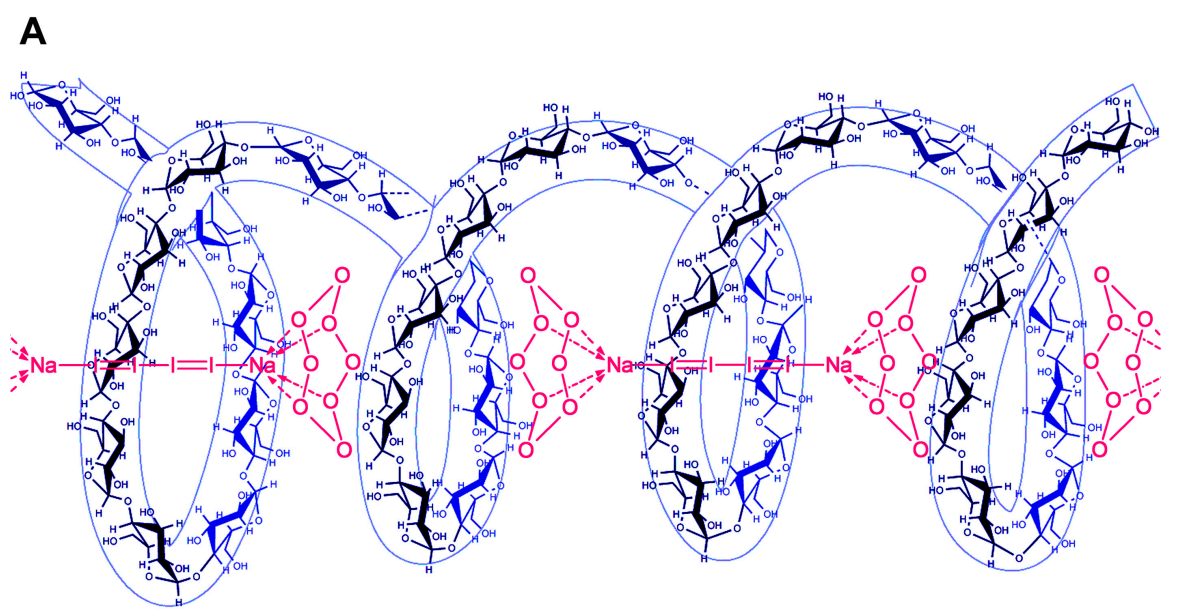

B

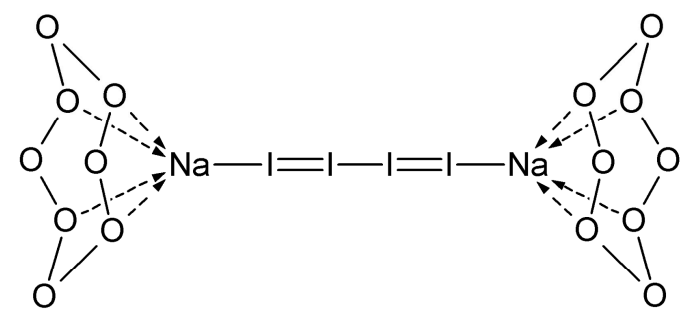

bis $\left(\right.$ octoxocane- $\left.\kappa^{4} O^{1}, O^{3}, O^{5}, O^{7}\right)\left(\mu-2 \lambda^{3}, 3 \lambda^{3}\right.$-tetraioda-1,3-diene-k $\left.l^{1}: \kappa l^{4}\right)$ disodium

C

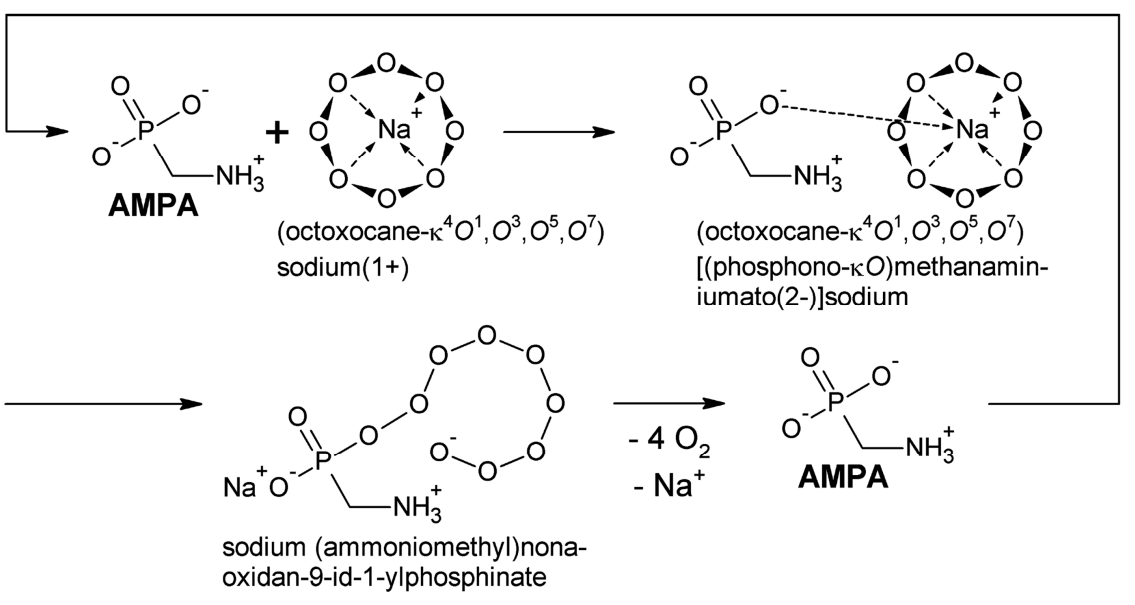

Figure 8. Explanation of the color reaction for cyclo- ${ }_{8}-\mathrm{Na}^{+}$contained in $\mathrm{RC}$, and the destruction of cyclo$\mathrm{O}_{8}-\mathrm{Na}^{+}$by the glyphosate metabolite (aminomethyl)phosphonic acid (AMPA). (A) The cyclo-O8- $\mathrm{Na}^{+}$ complex contained in $\mathbf{R C}$ reacted with potassium iodide under catalysis by potato starch to an intensely colored (reddish violet) [(cyclo-O $\left.\left.{ }_{8}-\mathrm{Na}^{+}\right)_{2}\left(\mathrm{I}_{4}{ }^{2-}\right)\right]$ complex stabilized within the starch-contained amylose helix. (B) The proposed chemical formula for the amylose-complexed [(cyclo-O $\left.\left.8-\mathrm{Na}^{+}\right) 2\left(\mathrm{I}_{4}{ }^{2-}\right)\right]$ :

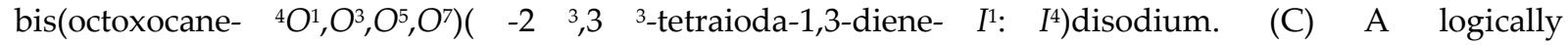
deduced catalytic 'rolling-circle' mechanism for the AMPA-catalysed degradation of cyclo-Os- $\mathrm{Na}^{+}$. The cycloocytooxygen ring is split to a phosphonate-esterified nonaoxidanide which is stabilized by ionic binding to the primary ammonium cation of AMPA. The phosphonate-esterified nonaoxidanide eliminates four oxygen $\mathrm{O}_{2}$ molecules by a 'rolling-circle' cascade, regenerating AMPA. 


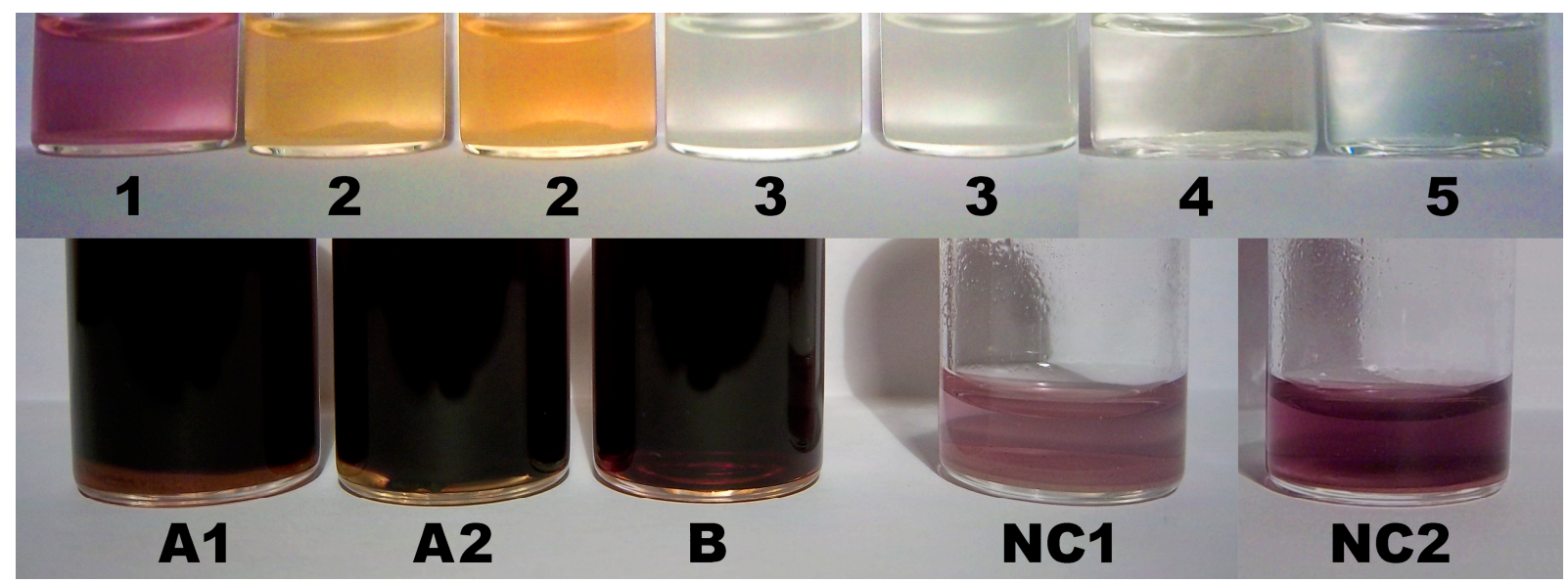

Figure 9. Color assays for the destruction of cyclo- $\mathrm{O}_{8}-\mathrm{Na}^{+}$contained in $\mathbf{R C}$ by glyphosate and ROUNDUP® GRAN (top, 1-5), for the potential reduction of elemental iodine by glyphosate and ROUNDUP® GRAN (bottom, A1, A2, and B), and for cyclo-O8- $\mathrm{Na}^{+}$contained in NC (bottom, NC1 and NC2). Solutions (top, 1-5) were: RC + KI + starch (1), RC + KI + starch + glyphosate (free acid) (2), RC + KI + starch + ROUNDUP® GRAN (3), RC + KI + glyphosate (free acid) (4), and RC + KI + ROUNDUP® GRAN (5). The concentrations in solution were: RC, $16.95 \mathrm{mM}$ (with cyclo-Os- $\mathrm{Na}^{+}, 67.79 \mathrm{mM}$ ); KI, 171.69 mM; glyphosate, $100.55 \mathrm{mM}$; glyphosate-Na, $108.15 \mathrm{mM}$. The solutions were incubated at two room temperatures for prolonged time. Legend (bottom): (A1) glyphosate (free acid, $102.52 \mathrm{mM}$ ) + iodine (as $\mathrm{I}_{2}$, $98.50 \mathrm{mM}$ ), (A2) ROUNDUP® GRAN (glyphosate-Na, $102.77 \mathrm{mM}$ ) + iodine (as I2, $98.50 \mathrm{mM})$, (B) iodine (as I2, $98.50 \mathrm{mM}),(\mathbf{N C 1}, \mathbf{N C} 2)$ NC (18.25 mM, with cyclo-Os-Na+, $18.25 \mathrm{mM})+\mathrm{KI}(259.04 \mathrm{mM})$ after $10 \mathrm{~h}$ (NC1) and $50 \mathrm{~h}$ (NC2) incubation.

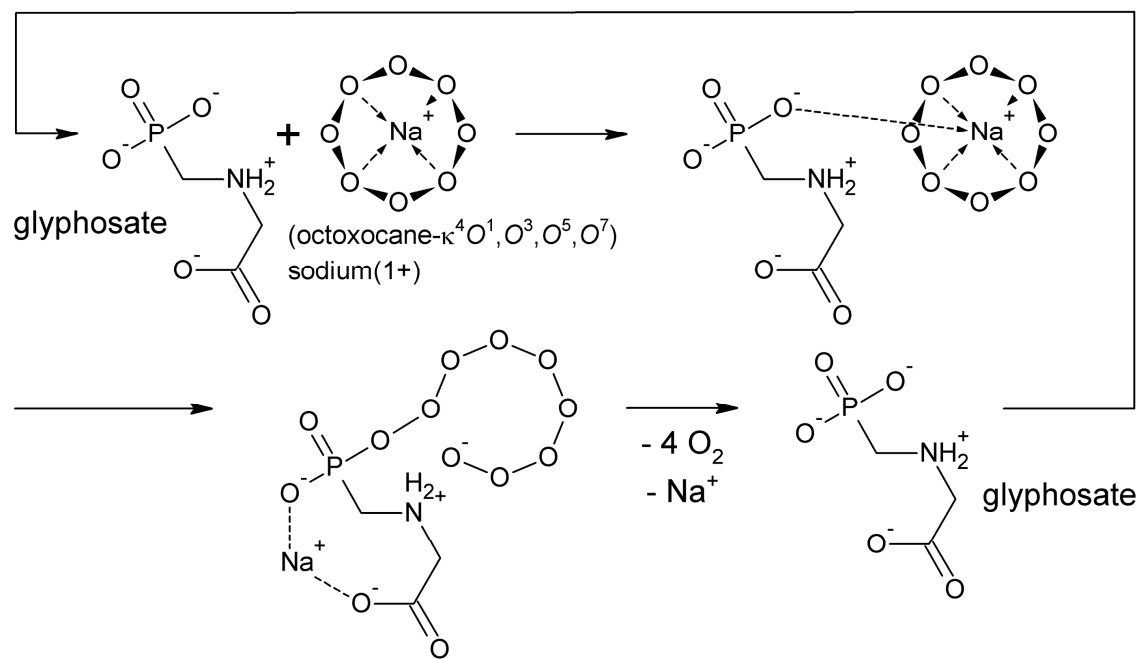

Figure 10. A logically deduced catalytic 'rolling-circle' mechanism for the (fully ionized) glyphosatecatalysed degradation of cyclo-Os- $\mathrm{Na}^{+}$. The cycloocytooxygen ring is split to a phosphonate-esterified nonaoxidanide which is stabilized by ionic binding to the secondary ammonium cation of glyphosate (and complexation of the sodium cation). The phosphonate-esterified nonaoxidanide eliminates four oxygen $\mathrm{O}_{2}$ molecules by a 'rolling-circle' cascade, regenerating glyphosate. 
A

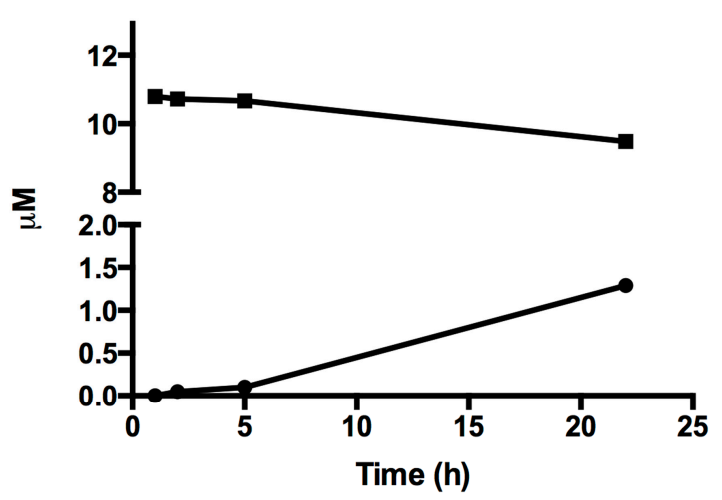

B

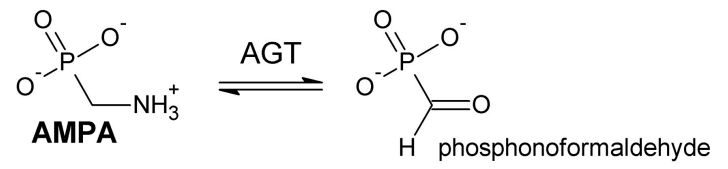

Figure 11. The catabolism of AMPA by human peroxisomal alanine:glyoxylate aminotransferase (AGT). (A) Time course of the AMPA half-transamination reaction of human AGT. The enzyme at a concentration of $5 \mu \mathrm{M}$ was incubated at $25^{\circ} \mathrm{C}$ in $100 \mathrm{mM}$ potassium phosphate buffer ( $\mathrm{pH}$ 7.4). At the indicated times, aliquots were withdrawn and denatured. After removal of the precipitated protein by centrifugation, the supernatants were subjected to HPLC analysis (squares, PLP; circles, PMP). (B) The generation of phosphonoformate (foscarnet) from AMPA over the intermediate phosphonoformaldehyde by the rate-limiting transamination of the major environmental glyphosate metabolite AMPA. Phosphonoformaldehyde, seen as an glyoxylate analogue, could be oxidized by glycolate oxidase (GO) and lactate dehydrogenase (LDH) [73]. Foscarnet is a potent inhibitor of eukaryotic DNA polymerase $[74,75]$, an enzyme crucially involved in maintaining chromosomal integrity and telomere length.

$$
\begin{aligned}
& \text { A } \mathrm{pK}_{\mathrm{a}, \mathrm{HG}}^{\prime}=\frac{8}{3}(n-1)+\mathrm{p} K_{\mathrm{a}, \mathrm{R}-\mathrm{OH}}=7.1849 \\
& \text { with }(n-1)=\frac{0.821 \times 10^{-5} \mathrm{~cm} \times \lambda}{\sqrt[3]{2 \lambda^{\prime} s j b^{2}}} \text {, and } \lambda=1+\ln \frac{3 h_{v}^{2}}{2 h_{0}^{2}} ; \lambda^{\prime}=\ln \frac{3 h_{v}^{2}}{2 h_{0}^{2}}-1 \\
& \text { B } \mathrm{pH}_{\mathrm{DNA}}=-\log _{10} \sqrt{10^{-\mathrm{p} K_{\mathrm{a}, \mathrm{HG}} \times c_{\mathrm{DNA}} \times 3,238,442,024 \times 2 \times 2.6862 \%}}=1.6642 \\
& \mathrm{pH}_{\text {spermine }}=-\log _{10} \sqrt{\frac{10^{-14} \times 10^{-\mathrm{p} K_{\text {'spermine }}}}{c_{\mathrm{DNA}} \times \frac{1}{4} \times 3,238,442,024 \times 2.6862 \%}}=13.1867 \\
& \mathrm{pH}_{\text {shell }}=-\log _{10} \sqrt{\frac{10^{-14} \times 10^{-\mathrm{p} K_{\text {shell }}}}{c_{\mathrm{DNA}} \times \frac{2}{3} \times 3,238,442,024 \times 2.6862 \%}}=13.1708
\end{aligned}
$$

Figure 12. The calculation of the apparent acid dissociation constant of the haploid human genome, and of the interphase intranuclear micro-pH values induced by human genome depending on its intrinsic epigenetic occupation status. (A) The calculation of the apparent (effective) $\mathrm{pK}^{\prime}{ }_{\mathrm{a}, \mathrm{HG}}\left(25^{\circ} \mathrm{C}\right)=7.1849$ of the haploid human genome according to the method of Katchalsky \& Gillis [58] and Kuhn \& Kuhn [59] [pK' ${ }_{a, \mathrm{HG}}$ $=$ apparent acid dissociation constant $\left(25^{\circ} \mathrm{C}\right)$ of haploid $H$. sapiens genome $\mathrm{B}-\mathrm{DNA}$ double helix; $\mathrm{pK} K_{\mathrm{a}, \mathrm{R}-\mathrm{OH}}=$ $1.29=$ theoretical $\mathrm{p} K_{\mathrm{a}}\left(25^{\circ} \mathrm{C}\right)$ [86] of one isolated internucleotide phosphodiester $(\mathrm{R}-\mathrm{OH})$ proton; $s=1=$ number of statistical subunits on thread molecule [59]; $j=6=$ number of spacing atoms (at least distance) in one dsDNA repeating unit [59]; $b=0.334 \times 10^{-7} \mathrm{~cm}(0.334 \pm 0.01 \mathrm{~nm}[87])=$ length rise in $\mathrm{cm}$ of one B- 
DNA repeating unit (helix rise/bp) in solution; $h=$ end-to-end distance of dsDNA at halfneutralization; $h_{0}=$ end-to-end distance of dsDNA]. (B) The theoretical micro-pH values surrounding $H$. sapiens haploid (and diploid) interphase euchromatin were calculated as the intranuclear micro-pH induced by human haploid (and diploid) genome treated as a weak acid, from pHDNA, $\mathrm{pH}_{\text {spermine, and }}$ $\mathrm{pH}$ shell, by applying the formula for $\mathrm{pH}$ induced by weak acids: $\mathrm{pH}=-\log _{10}\left(K_{\mathrm{s}} \times \mathcal{C}_{\mathrm{s}}\right)$, or the formula for $\mathrm{pH}$ induced by weak bases: $\mathrm{pH}=-\log _{10}\left[\left(K_{\mathrm{w}} \times K_{\mathrm{s}}\right) \times\left(c_{\mathrm{s}}\right)^{-1}\right]\left(K_{\mathrm{s}}\right.$, acid dissociation constant; $\left.K_{\mathrm{w}}=10^{-14}\right)$. The intranuclear micro-pH was calculated by the law for the calculation of the solution $\mathrm{pH}$ induced by salts of weak acids with weak bases: $\mathrm{pH}_{\text {salt }}=0.5 \times\left(\mathrm{pH}_{\text {acid }}+\mathrm{pH}\right.$ base $)$. 


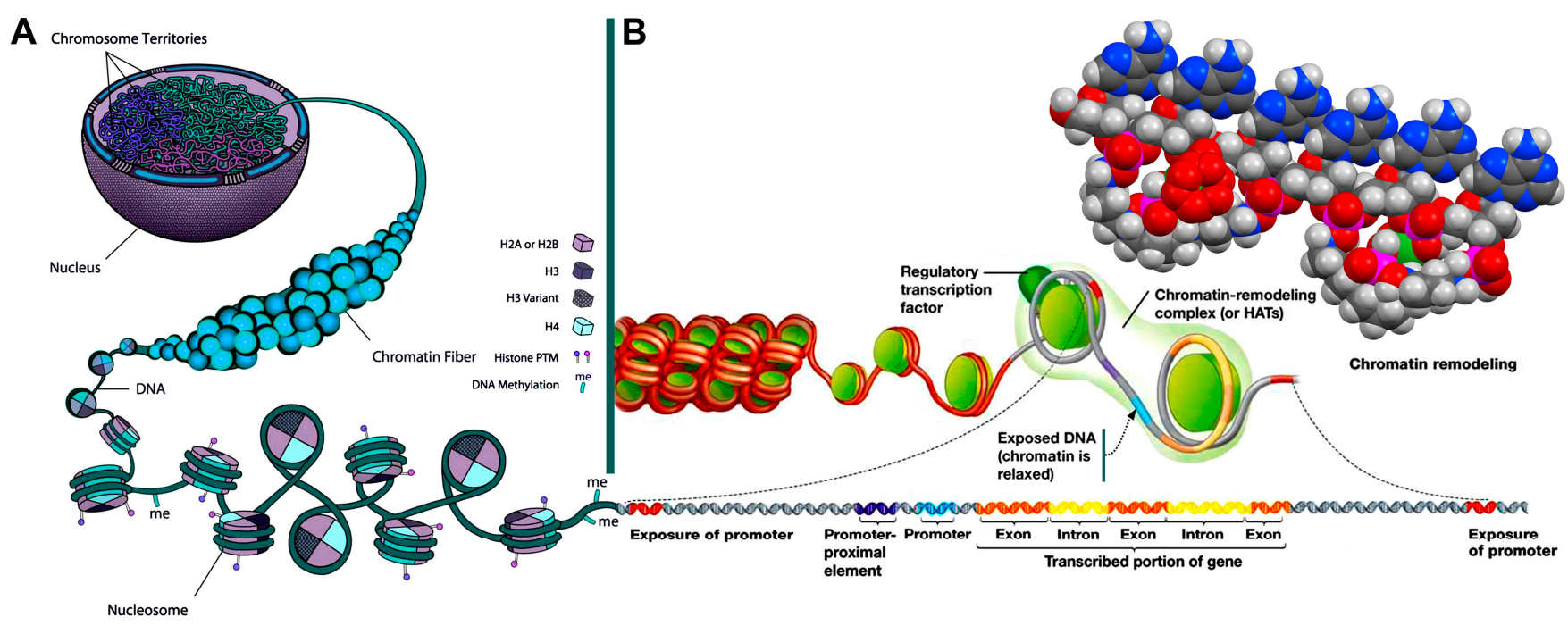

Figure 13. An improved and corrected model for the cyclooctaoxygen sodium-bridged spermine phosphate (and selenite) epigenetic shell [5] of actively transcribed gene regions in eukaryotic interphase 'open' chromatin DNA. (A) The nucleus of an eukaryotic cell with chromosome territories, chromatin fiber (10 nm 'beads-on-a-string' fiber), nucleosome structure, nucleosome octamer core histone proteins [H2A/H2B, H3/H3 variant, H4] with posttranslational histone protein modifications (histone PTM), and decondensing DNA with regulative cytosine nucleobase 5-methylation sites (me). Adapted and modified in part from [95]. (B) The decondensation of chromatin enabling gene transcription in eukaryotic interphase 'open' chromatin DNA. The relaxed chromatin, regulatory transcription factor, chromatinremodeling complex/histone acetyl transferases (HATs), and chromatin remodeling are indicated. The 'open' DNA with the transcription-prone gene is generally structured in promoter, promoter-proximal genetic elements, transcribed/expressed gene exons and non-expressed gene introns. The cyclooctaoxygen sodium-bridged spermine phosphate (and selenite) epigenetic coverage of this actively transcribed gene region is symbolized. 

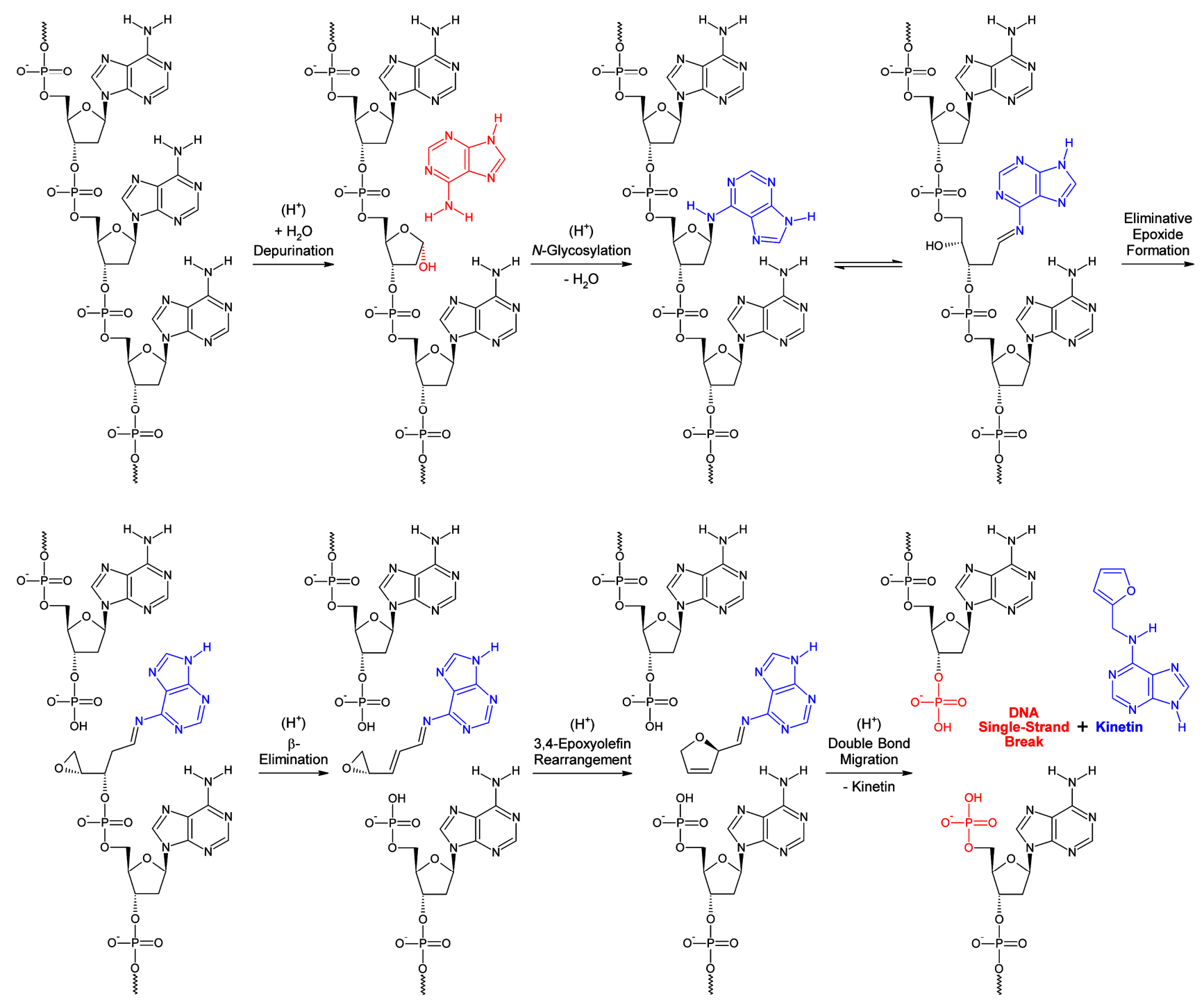

Figure 14. A chemical mechanistic deduced logical scheme for the generation of kinetin ( $\mathrm{N}^{6}$-furfuryl-9Hadenine) [106] from DNA by proton catalysis (kinetin-generating "base flip", KGBF). Protonation of the adenine nucleobase of the shown $d(p A p A p A p)$ sequence at purine N-7 induces depurination [103,104], creating an apurinic site [103-105]. Proton-catalysed $\mathrm{N}$-glycosylation [110,111] at the 6- $\mathrm{NH}_{2}$ of adenine regenerates a nucleobase-inverted 2'-deoxynucleotide which is in furanose ring-opening equilibrium with its ald(os)imine form. Two eliminations simultaneously follow, the first (auto-catalysed by 3'-Ophosphate conjugate base proton reception) by $\mathrm{S}_{\mathrm{N}} 2$-nucleophilic eliminative epoxide formation, the second by proton-catalysed (auto-catalysed by the previously liberated 3'-O-monohydrogen phosphate conjugate acid) -elimination (E1 unimolecular elimination), which leads to an 3,4-epoxyolefin: $\mathrm{N}$ $\{(1 E, 2 E)-3-[(2 S)$-oxiran-2-yl]prop-2-en-1-ylidene\}-9H-purin-6-amine. The chiral (S)-2-vinyloxirane structure rearranges to a chiral (R)-2-alkyl-2,5-dihydrofuran due to 3,4-epoxyolefin rearrangement [111,112]: $N-[(2 R)-2,5$-dihydrofuran-2-ylmethyl]-9H-purin-6-amine. The latter compound rearranges to kinetin through facile double bond migration driven by aromatization to a furan. A DNA single-strand break is left back. 